Szymon Bauman

(Poznań)

mgr, szybau@gmail.com

ORCID iD: 0000-0002-2580-4385

Paulina Chrząszcz

(Instytut Historii PAN, Warszawa)

mgr, paulina.chrzaszcz93@gmail.com

ORCID iD: 0000-0002-1370-3237

\title{
Wytwórcy i sprzedawcy pieczęci ogłaszający się w prasie poznańskiej w latach 1815-1939
}

Badania nad sfragistyką XIX i XX w. nie cieszyły się - jak dotąd - szczególnym zainteresowaniem polskich badaczy pieczęci ${ }^{1}$. Wśród wielu zagadnień, które czekają na opracowanie, jest pilna potrzeba rozpoznania działalności pieczętarzy ${ }^{2}, \mathrm{w}$ tym ustalenie $\mathrm{z}$ imienia i nazwiska listy czynnych wytwór-

${ }^{1} \mathrm{~W}$ dotychczasowych badaniach sfragistycznych podejmowano jedynie fragmentarycznie problematykę pieczęci XIX i XX w., która ograniczała się do sfery państwowej, miejskiej, wiejskiej, kościelnej, cechowej, rzadziej uniwersyteckiej i prywatnej. Osobnych opracowań doczekały się np. pieczęcie powstańcze, w szczególności władz powstania styczniowego. Materiał sfragistyczny z omawianego okresu znalazł odbicie przede wszystkim w badaniach regionalnych (sfragistyka miejska lub wiejska). Nieco obszerniejszą literaturę posiadają pieczęcie i stemple pocztowe z dwóch ostatnich stuleci, wyraźnie zaś uboższą m.in. pieczęcie wojskowe. Ostatnio literaturę polskojęzyczną dotyczącą sfragistyki XIX i XX stulecia zebrał w pracy magisterskiej S. Bauman, Krakowska firma rytowniczo-pieczętarska Aleksandra Fischhaba, Poznań 2018, przypisy 17-30 (praca magisterska napisana pod kierunkiem dr. hab. Pawła Stróżyka, prof. UAM, dostępna w Archiwum Prac Dyplomowych Wydziału Historycznego UAM w Poznaniu).

${ }^{2}$ Literatura prezentująca wytwórców pieczęci została wstępnie zebrana w innym miejscu, zob. S. Bauman, P. Chrząszcz, Warszawski zakład pieczętarski Zygmunta Weinkrantza, [w:] Żydzi polscy na przestrzeni wieków. Materiaty z III Krakowskiej Konferencji Judaistycznej, red. S. Gąsiorowski, Kraków 2018, s. 12, przypis 3. Należy ją jeszcze uzupełnić o następujące pozycje: E. Szulc, Materiały do biografii medalierów, grawerów stempli, pracowników mennicy i numizmatyków w świetle akt parafii ewangelickich w Warszawie, „Wiadomości Numizmatyczne” 1982, r. XXVI, z. 1-2, s. $33-$ 47; R. Bobrow, Złotnicy i jubilerzy prowincji Królestwa Polskiego, Warszawa 2017; tegoż, Warszawscy złotnicy, jubilerzy, grawerzy i kupcy wyrobów kruszcowych w XIX wieku, Warszawa 2018; S. Bauman, 
ców i sprzedawców pieczęci, rozpoznanie ich środowisk rodzinnych oraz ich statusu społecznego, następnie ukazanie zmian w technice pracy czy poznanie sposobów reklamowania.

Wychodząc naprzeciw wspomnianym potrzebom badawczym sfragistyki ostatnich dwóch stuleci, należy najpierw zaprezentować wyniki badań nad ogłoszeniami prasowymi wytwórców, które zamieszczano na łamach gazet ukazujących się w stolicy Wielkopolski. Tego typu materiał źródłowy umożliwił m.in. sporządzenie wstępnego wykazu grawerów pieczęci działających w Poznaniu w latach 1815-1939.

Informacje dotyczące osób wytwarzających i sprzedających pieczęcie odnaleźć można także w: cennikach i katalogach firmowych, drukach ulotnych, księgach adresowych i telefonicznych, skorowidzach oraz wszelkich innych spisach firm i branż. Takie źródła pomagają zweryfikować i uzupełnić dane pozyskane z anonsów prasowych oraz ustalić nazwiska tych pieczętarzy, którzy nie zamieszczali swoich ogłoszeń na łamach gazet, czego przykładem są znakomici poznańscy wyrzynacze pieczęci drugiej połowy XIX w. - Fryderyk Wilhelm Below i Feliks Dmochowski. Warto również odnotować, że w prasie poznańskiej ogłaszały się wytwórnie pieczęci z innych miast, takich jak: Berlin, Bochum i Wrocław.

W trakcie kwerendy odnaleziono ogłoszenia oraz informacje dotyczące następujących wytwórców i sprzedawców pieczęci: Fryderyka Wilhelma Belowa i jego syna, Stefana Jakuba Belowa (Poznań), Arnolda Berga (Poznań) ${ }^{3}$, Czesława[?] Chrzanowskiego (Poznań), K. Chwinowskiego (Poznań), Feliksa Dmochowskiego (Poznań), Johanna Gustava Ehlerta (Poznań), Salomona Elkelesa (Poznań), Mara Hübscha (Wrocław), Instytutu Heraldycznego "Gryf" (Poznań), I. Jóźwiaka (Poznań), Theodora Kaisera (Berlin), Ludwika i Bolesława Kapelów (Poznań), A. Kirstena (Berlin), Stefana Kominowskiego (Poznań), Eligiusza Kromczyńskiego (Poznań), Wolffa Loewenthala (Poznań), Józefa Lorenza (Bochum), Edwarda Nichtera (Poznań), Franciszka Piekuta (Poznań), Paula Radkego (Poznań), Maxa Rothenburga (Poznań), Fryderyka Schmidta (Poznań), L. Schmidta (Poznań), Władysława i Maksymiliana Seydlitzów (Poznań), Bernarda Skorupskiego (Poznań), Karola Steinberga (Poznań), Ludwika Szmyta (Poznań) oraz spółkę „Wąsik \& Godlewski" (Poznań). Potencjalni wytwórcy typariuszy mogą się kryć również

Krakowska rodzina Fischhabów i jej firma rytowniczo-pieczętarska w latach 1900/1904-1950, [w:] Cracoviensis civitas - singulare totius Poloniae decus. Materiaty z I oraz II Ogólnopolskiej Studencko-Doktoranckiej Konferencji Naukowej „Kraków na przestrzeni dziejów”, red. nacz. M. Chruściak, red. nauk. Z. Piech, M. Stinia, Kraków 2018, s. 207-232.

${ }^{3}$ Arnold Berg - administrator zastępczy (Kommissarischer Verwalter) w firmie L. Kapela, która została zagrabiona przez okupanta niemieckiego w czasie II wojny światowej. Ze względu na jego funkcjonowanie po 1939 r. stanowi pewien wyjątek w przyjętej chronologii dla niniejszego opracowania. 
wśród osób, figurujących w spisach branż metalowych jako rytownicy lub grawerzy ${ }^{4}$. Wymieniono wśród nich: Jana Białasa ${ }^{5}$, Ludwika Brandta ${ }^{6}$, Wilhelma Böhma7 ${ }^{7}$ Paula Cammerzellego, Tomasza Dudzika ${ }^{8}$, Eitiga, spół-

${ }^{4}$ Lista grawerów i rytowników została opracowana na podstawie spisów w księgach, książkach i skorowidzach adresowo-handlowych Poznania, ale również niekiedy dotyczących danego regionu lub innego miasta bądź obejmujących obszar całej Polski: Posener Wohnungs-Anzeiger auf das Jahr 1855, s. 136; tamże, 1862, s. 57; tamże, 1865, s. 66; Adressbuch für die Stadt Posen, Posen 1872, Abt. I, s. 43; tamże, 1876, Abt. II, s. 96; Adress- und Geschäfts-Handbuch der Stadt Posen, Posen 1879, 1882, 1885, 1890-1893; Adressbuch der Stadt Posen, Posen 1886-1889; Ksiażka adresowa handlu i przemystu Polskiego w obrębie niemieckiego państwa obejmująca adresy fabrykantów, kupców i samodzielnych rzemieślników, r. 1: 1896-1897, s. 212 (rytownicy) i 241 (złotnicy i jubilerzy); Adressbuch der Stadt Posen sowie der Vororte Bartholdshof, Jersitz, St. Lazarus und Wilda. 1898, Abt. IV, s. †15; Adressbuch der Stadt Posen sowie der Vororte Jersitz, St. Lazarus und Wilda. 1899, Abt. IV, s. †15; Adressbuch der Provinzial-Hauptstadt Posen sowie der Vororte Jersitz, St. Lazarus und Wilda 1900, Abt. IV, s. 231*; Adressbuch der Provinzial-Hauptstadt Posen für das Jahr..., Posen 1901-1904; Adressbuch der Provinzial-Hauptstadt Posen, Posen 1905-1908, 1910; Adressbuch der Provinzial-Haupt und Residenzstadt Posen, Posen 1911, Abt. IV, s. 267*; Adressbuch der Residenzstadt Posen, Posen 1912-1914; Adressbuch der Residenzstadt Posen, Posen 1916-1917; Ksiażka Adresowa Miasta Stołecznego Poznania 1926, cz. III, Spis branż i zawodów, s. 355* (oznaki), 367* (rytownictwo); Księga Adresowa Polski (wraz z w. m. Gdańskiem) dla handlu, przemystu, rzemiost i rolnictwa 1926/27, s. 719 (rytownictwo) i 722 (stemple); tamże, 1928, s. 1413 (grawerzy); tamże, 1930, s. 1387 (grawerzy); Ksiegga Adresowa Miasta Stotecznego Poznania na rok 1930, Dział Branż i Zawodów, s. LVII; Ksiegga Adresowa Miasta Stołecznego Poznania na rok 1933, Dział III, s. 10 (jubilerzy) i 22 (rytownicze zakłady); Księga Adresowa dla Handlu - Przemystu - Rzemiosta Stot. M. Poznania 1936-37, s. 65 (rytownictwo); Księga Adresowa Polski: przemystu, handlu, finansów, szkolnictwa, wolnych zawodów i organizacji społecznych, Warszawa 1937, s. 734-735.

${ }^{5}$ Ur. 19 września 1866 r. w Bukówcu Górnym, zm. 11 lipca 1905 r. w Poznaniu. Jego żoną była Stanisława z d. Curzyńska, ur. 5 marca 1882 r. w Poznaniu, z którą wziął ślub 17 listopada 1903 r. Z tego małżeństwa urodziła się dwójka dzieci: Marian i Stefan. Jan Białas był z zawodu zegarmistrzem. Szerzej na jego temat zob. m.in. Archiwum Państwowe w Poznaniu [dalej: APP], Akta miasta Poznania - Kartoteka ewidencji ludności 1870-1931 [dalej: AmP - Kartoteka], sygn. 14279, k. 74-75; S. Gibasiewicz, Białas Jan (1866-1905), [w:] Wielkopolski słownik biograficzny [dalej: WSB], Warszawa-Poznań 1981, s. 51-52; W. Karolczak, Biżuteria i zegarki z polską symbolika patriotyczna w sklepach jubilerskich w Poznaniu pod koniec XIX wieku, „Kronika Miasta Poznania” [dalej: KMP] 2000, nr 1, s. 163-169; Z. Dolczewski, "Salonik damski" $i$ „Pokój męski w tyrolskim gotyku". Wyposażenie domów z poznańskich wytwórni w XIX w., KMP 1994, nr 1-2, s. 172-173.

${ }^{6}$ Ur. 17 listopada 1879 r. w Łodzi. Jego żoną była Anna z d. Wandt, ur. 1 czerwca 1879 r. w Berlinie. Z tego małżeństwa urodziło się trzech chłopców: Tytus, Hugo i Helmut. Ludwik był z zawodu grawerem, z wyznania ewangelik. W 1920 r. rodzina Brandtów przeprowadziła się z Łodzi do Poznania, gdzie zamieszkała na Wałach Zygmunta Augusta 4, zob. APP, AmP Kartoteka, sygn. 14304, k. 222-223.

${ }^{7}$ Ur. 26 marca 1854 r. w Żabnie koło Śremu. Jego pierwszą żoną była Wilhelmina z d. Schwarz (1839-1892), z którą miał syna - Johanna Wilhelma. Po śmierci pierwszej żony Wilhelm ożenił się ponownie. Jego drugą żoną była Emma z d. Jander, ur. 28 sierpnia 1868 r., z którą miał siedmioro potomnych, zob. APP, AmP - Kartoteka, sygn. 14271, k. 126-128.

${ }^{8}$ Ur. 4 lutego 1896 r. w Wanne niedaleko Gelsenkirchen w Niemczech. Jego rodzicami byli: Marcin i Antonina z d. Mondra (Mądra?). W 1922 r. Tomasz ożenił się z Marią z d. Bocheńską, z którą miał dwójkę dzieci: Mariana i Henryka. Rodzina Dudzików mieszkała od 1922 r. w bu- 
kę "Gąsiorowski i Frankowski"9, Stefana Gromadzińskiego, Fryderyka Hietzscholda $^{10}$, Jana Jakubowskiego ${ }^{11}$, Karola Kandziorę ${ }^{12}$, Franciszka Knakowskiego ${ }^{13}$, Mariana Michonia, Józefa Pendowskiego ${ }^{14}$, Issaka Pinnera, Stanisława Przespolawskiego, Sachsa, Schollmeyera, Alfreda ${ }^{15}$ i Stanisława Słupczyńskich ${ }^{16}$, Waleriana Szulca ${ }^{17}$, Isidora Stammreicha ${ }^{18}$, G. Webera, Józefa Zielińskiego ${ }^{19}$ oraz Stefana Zygmaniaka ${ }^{20}$.

dynku przy ul. Ułańskiej 2, a pod koniec sierpnia 1925 r. przeprowadziła się na ul. Drużbacką 1a w Poznaniu, zob. APP, AmP - Kartoteka, sygn. 14369, k. 504-505.

${ }^{9}$ Spółkę współtworzyli: Tadeusz Gąsiorowski i Stanisław Frankowski (złotnik i rytownik).

${ }^{10}$ Ur. 21 grudnia 1873 r. Jego rodzicami byli: Fryderyk i Józefina z d. Rudolf. Żoną jego była Agnes z d. Wiegner, ur. 16 kwietnia 1875 r. w Hamburgu. F. Hietzschold był z zawodu grawerem, który przybył z Lipska do Poznania na początku XX w., zob. APP, AmP - Kartoteka, sygn. 14505, k. 1021.

${ }^{11}$ Ur. 1 marca 1901 r. w Naramowicach (obecnie część Poznania). Rodzicami jego byli: Andrzej i Katarzyna z d. Hojnacka. W 1928 r. ożenił się z Marianną z d. Kowalską, ur. 31 maja 1904 r. w Rybnie pod Krakowem. Małżeństwo od początku mieszkało na Naramowicach. Jan Jakubowski był z zawodu rytownikiem, zob. APP, AmP - Kartoteka, sygn. 14526, k. 171. Warto w tym miejscu przypomnieć, że ostatnio powstało opracowanie dotyczące późniejszej działalności firmy Jana Jakubowskiego prowadzonej przez jego syna Jarosława, zob. J. Łuczak, Arcydzieła sztuki grawerskiej. Kolekcja odznak wojskowych z pracowni Jarosława Jakubowskiego z Poznania ofiarowana do zbiorów Wielkopolskiego Muzeum Wojskowego, Poznań 2016.

12 Ur. 2 listopada 1882 r. w Dreźnie obok Żnina. Jego żoną była Aniela z d. Chrzanowska, ur. 22 lutego 1889 r. w Jassy (Rumunia). Małżeństwo Kandziorów doczekało się trójki dzieci. Karol był z zawodu zegarmistrzem, zob. APP, AmP - Kartoteka, sygn. 14580, k. 349-350; A. Małecki, Kandziora Karol Marcin (1882-1944), [w:] WSB, s. 313.

${ }^{13}$ Ur. 23 lipca 1884 r. w Magdeburgu. Jego żoną była Gertruda z d. Beyer, ur. 29 lipca 1881 r. w Jaworze. Z tego małżeństwa urodziła się czwórka dzieci. Franciszek wyuczył się grawerstwa, zob. APP, AmP - Kartoteka, sygn. 14621, k. 440-441.

${ }^{14}$ Ur. 11 czerwca 1876 r. w Kostrzynie. Ożenił się z Hedwig z d. Oduszewską, ur. 15 października 1878 r. w Wierzenicy niedaleko Poznania. Z tego małżeństwa urodziło się ośmioro dzieci. Józef był grawerem, zob. APP, AmP - Kartoteka, sygn. 14911, k. 149-151.

${ }^{15}$ Grawer, ur. 10 lipca 1882 r. w Krakowie. Jego żoną była Amelia z d. Tiel, ur. 10 lutego 1898 r. w Sosnowcu. Prowadził zakład rytowniczy, który być może przejął od starszego brata Stanisława i przeniósł jego siedzibę na przełomie lat 20. i 30. XX w. na Plac Wolności 17 w Poznaniu, zob. APP, AmP - Kartoteka, sygn. 15049, k. 778-779.

${ }^{16}$ Rzeźbiarz, ur. 9 lutego 1879 r. w Krakowie. Jego żoną była Julia z d. Brzesucka. Małżeństwo doczekało się dwóch córek - Eleonory i Eugenii. Stanisław był prawdopodobnie bratem Alfreda Słupczyńskiego. W latach 20. XX w. prowadził zakład grawerski przy ul. Wielkie Garbary 36 w Poznaniu, zob. APP, AmP - Kartoteka, sygn. 15049, k. 780-781.

${ }^{17}$ D. Sokolnicka, Szulc Walerian (1849-1901), [w:] WSB, s. 744-745; K. Męczyńska, Poznańskie rody i rodziny - Szulcowie: Muzeum Narodowe w Poznaniu: wystawa 2 kwietnia - 22 maja 2006 w Muzeum Historii Miasta Poznania - Ratusz, Poznań 2006, s. 18-26; W. Karolczak, Biżuteria i zegarki..., s. 170-173.

${ }^{18}$ Ur. 17 maja 1853 r. Poza datą urodzenia wiemy jedynie tyle, że był z zawodu grawerem, który przybył do Poznania z Wielunia, zob. APP, AmP - Kartoteka, sygn. 15074, k. 1015.

${ }_{19}$ Być może wspomniany zakład grawerski Józefa Zielińskiego w pracy Jacka Strzałkowskiego, był prowadzony przez poznańskiego rzemieślnika, który na początku XX w. wy- 
Poniższy wykaz powstał na marginesie przygotowywanych materiałów do słownika wytwórców pieczęci z terenów polskich w XIX i XX w., które będą kontynuacją wcześniejszych badań autorów i ich współudziału w organizacji wystawy pt. Wytwórcy pieczęci ogłaszajacy się w prasie poznańskiej w latach 1815-191421, będącej zwieńczeniem projektu realizowanego $\mathrm{w}$ latach 2015-2017 przez członków Sekcji Źródłoznawstwa i Nauk Pomocniczych Historii Studenckiego Koła Naukowego Historyków im. Gerarda Labudy przy Instytucie Historii Uniwersytetu im. Adama Mickiewicza w Poznaniu22. Dlatego niniejszy tekst ma charaktery przyczynkowy, przede wszystkim bierze sobie za cel opublikowania zebranego materiału źródłowego, który pozwoli na dalsze rozwijanie tego zagadnienia w przyszłych badaniach.

\section{Wykaz odnotowanych osób wykonujących lub oferujących sprzedaż pieczęci w prasie poznańskiej w latach 1815-1939}

Nie dysponujemy pełną dokumentacją do badań nad działalnością poszczególnych poznańskich osób i większych firm wytwarzających lub handlujących pieczęciami, w związku z czym informacje o niektórych zakładach ograniczają się do nazwiska właściciela, samej nazwy bądź jedynie adresu danego przedsiębiorstwa. Materiał archiwalny na temat niektórych zakładów zachował się fragmentarycznie. W paru przypadkach nie udało się niestety odnaleźć pieczęci wytworzonych przez występujące w ogłoszeniach pracownie. Niejednokrotnie trudno było ustalić daty powstania i zamknięcia danego sklepu, jego profilu i zmian lokalizacji. W następstwie takiego stanu rzeczy podane tu dane nie zawierają wielu informacji do dziejów poszczególnych firm ani pełnego materiału biograficznego, wszakże stanowią podstawę do dalszych poszukiwań i uzupełnień istniejących w literaturze życiorysów lub przyczynków na ich temat.

prowadził się z Poznania do Warszawy?, zob. J. Strzałkowski, Stownik medalierów polskich i z Polska zwiazanych 1508-1965. (Materiaty), Warszawa 1982, s. 131.

${ }^{20}$ Żył w latach 1896-1972. Z zawodu grawer i złotnik. W latach 30. XX w. prowadził swój warsztat przy ul. Półwiejskiej 38 w Poznaniu, zob. J. Strzałkowski, Stownik medalierów..., s. 131; Księga Adresowa Miasta Stołecznego Poznania na rok 1933, Dział III, s. 22; Księga Adresowa dla Handlu - Przemystu - Rzemiosta Stot. M. Poznania 1936-37, s. 65.

${ }^{21}$ Otwarcie wystawy miało miejsce 24 maja 2017 r. w Bibliotece Wydziału Historycznego UAM. Ekspozycje współtworzyli: Szymon Bauman, Paulina Chrząszcz i Karolina Czop.

22 Wykonawcami projektu byli: Szymon Bauman, Michał Bartoszak, Paulina Chrząszcz, Karolina Czop i Zuzanna Górnikiewicz. Opiekę naukową nad projektem sprawował dr hab. Paweł Stróżyk, prof. UAM. Kwerenda w ramach projektu objęła ponad pięćdziesiąt tytułów prasy poznańskiej. 
Wyjaśnienia wymagają sprawy zapisu. Pisownię imion i nazwisk odnotowujemy najczęściej za źródłem z epoki, choć w licznych przypadkach stosujemy polski zapis (np. w przypadku zapisu imion: Boleslaus - Bolesław, oraz Friedrich - Fryderyk). Do 1918 r. mieszkańców Poznania obowiązywała, bez względu na ich narodowość, pisownia w języku niemieckim. Niekiedy w przeciągu kilku dziesięcioleci pisano dwojako imię i nazwisko tych samych osób. Staraliśmy się zatem ujednolicić ich zapis. Podobny problemem występuje $z$ nazwami i numeracją ulic. W literaturze przedmiotu najczęściej podaje się nazwy ulic za źródłem. W niniejszym przypadku jest to o tyle problematyczne, że mowa będzie o co najmniej dwóch bytach państwowych - pruskim i polskim (po 1918 r.), oraz w jednym wypadku - wojennym (w latach 1939$1945)^{23}$. Aby poniższy wykaz zyskał na przejrzystości, nazwy poznańskich ulic zapisujemy według obecnie obowiązujących (w nawiasach okrągłych) ${ }^{24}$, nazwy zaś polskich miast zapisujemy za każdym razem w języku polskim.

BELOW, Fryderyk Wilhelm (ur. 15 marca 1822 r. w Rawiczu - zm. 19 lipca 1895 r. w Poznaniu) ${ }^{25}$. Był najstarszym spośród czworga dzieci Jana Fryderyka Belowa i Joanny Katarzyny Huie. W 1855 r. ożenił się z Karoliną Błaszczyńską, z którą miał ośmioro dzieci. Dwoje z nich - Stefan i Jadwiga - przeżyło rodziców i poszło w ślady ojca ${ }^{26}$. Below wraz z rodziną kilkakrotnie zmieniał miejsce zamieszkania w Poznaniu, były to następujące ulice: Wrocławska 33 (w latach około 1855-1874) ${ }^{27}$, tamże pod numerem 19 (w latach około 1874-1886) (28, $^{2}$ św. Marcin 5 (w latach około 1886-1927) ${ }^{29}$. Fryderyk zmarł 19 lipca 1895 r.

${ }^{23}$ Ostatnio podobne problemy sygnalizowała M. Mrugalska-Banaszak, Wilda w czterech odstonach 1235-1945, Poznań 2018, s. 10-11.

${ }^{24}$ Oprócz tego w nawiasach okrągłych zapisujemy niemieckojęzyczne nazwy pojęć, przedmiotów, wyuczonych i wymienianych w prasie zawodów danego rzemieślnika.

${ }^{25}$ APP, AmP - Kartoteka, sygn. 14270, k. 551-552. Fryderyk jest jedynym wytwórcą pieczęci, który został w znacznym stopniu opracowany. Literaturę na jego temat zebrał Szymon Bauman w komunikacie zamieszczonym w niniejszym tomie.

${ }^{26}$ Zob. niżej BELOW, Stefan Jakub.

Jadwiga Teresa (ur. 3 października 1866 r. w Poznaniu - zm. tamże 7 lipca 1927 r.). Rytowniczka, która po śmierci ojca - Fryderyka Wilhelma Belowa, prowadziła wraz z matką zakład pieczętarski przy ul. św. Marcin, zob. APP, AmP - Kartoteka, sygn. 14270, k. 551; np. Adressbuch der Provinzial-Hauptstadt Posen sowie der Vororte Jersitz, St. Lazarus und Wilda 1900, s. 12.

${ }^{27}$ Posener Wohnungs-Anzeiger auf das Jahr 1855, s. 5; tamże, 1862, s. 5; tamże, 1865, s. 6; tamże, 1868, s. 4; Adressbuch für die Stadt Posen 1872, s. 10.

${ }^{28}$ Adressbuch für die Stadt Posen 1876, s. 5; Adress- und Geschäfts-Handbuch der Stadt Posen 1885, s. 6; Adressbuch der Stadt Posen 1886, s. 6.

${ }^{29}$ Adress- und Geschäfts-Handbuch der Stadt Posen, 1890-1893; Adress- und Geschäfts-Handbuch der Stadt Posen nebst der vororte Bartholdshof, Berdychowo, Jersitz, St. Lazarus, Pietrowo und Wilda, 1894-1895. 
o godz. 8.00 wieczorem. Został pochowany na nieistniejącym dziś cmentarzu przy parafii św. Marcina w Poznaniu ${ }^{30}$.

Dzieciństwo spędził w rodzinnym mieście, dopiero wybór Prowincjonalnej Szkoły Przemysłowej (którą ukończył w 1840 r. z pochlebną opinią dyrektora szkoły) skłonił Fryderyka Wilhelma Belowa do przeprowadzki do Poznania. W latach szkolnych podjął praktykę u jednego z poznańskich grawerów. Po zakończeniu edukacji w 1842 r. udał się do stolicy Prus, gdzie kontynuował naukę zawodu. Pobyt w Berlinie nie trwał długo, ponieważ pojawiła się możliwość założenia własnego warsztatu w Poznaniu, z której zresztą Fryderyk skorzystał na przełomie lat $1844-1845^{31}$.

Fryderyk W. Below pozostawił po sobie wiele prac. Do najliczniej reprezentowanych przedmiotów trzeba zaliczyć - przede wszystkim - pieczęcie ${ }^{32}$, następnie medale, wyroby jubilerskie oraz inne prace wykonane w metalu, drewnie lub kamieniu ${ }^{33}$.

${ }^{30}$ Nekrologi: „Dziennik Poznański” z 21 lipca 1895, r. 37, nr 165, s. 6; „Dziennik Poznański” z 23 lipca 1895, r. 37, nr 166, s. 4; „Goniec Wielkopolski” z 21 lipca 1895, r. 19, nr 165, s. 3-4; „Goniec Wielkopolski” z 24 lipca 1895, r. 19, nr 167, s. 2.

${ }^{31}$ Na temat dalszej działalności artystycznej Fryderyka Wilhelma Belowa, zob. E. Majkowski, Fryderyk Wilhelm Below: pieczętarz i medaljer poznański, patriota polski (1822-1895), KMP 1936, r. 14, nr 3, s. 263-349.

$32 \mathrm{~W}$ wyniku przeprowadzonej kwerendy odnaleziono następujące typariusze wykonane przez F. W. Belowa: pieczęć bractwa rybackiego w Poznaniu (Muzeum Narodowe Rolnictwa i Przemysłu Rolno-Spożywczego w Szreniawie [dalej: MNRiPR-S], Zbiory historyczne, sygn. MNR H-1442); pieczęć parafii pw. św. Stanisława biskupa w Buku (APP, Tłoki, sygn. T IV, 2), pieczęć parafii pw. św. Apostołów Piotra i Pawła w Ptaszkowie (APP, Tłoki, sygn. T IV, 16), pieczęć kościoła kolegiackiego i parafialnego pw. św. Stanisława biskupa w Szamotułach (APP, Tłoki, sygn. T IV, 27), pieczęć parafii pw. Najświętszej Marii Panny w Zbąszyniu (APP, Tłoki, sygn. T IV , 50), pieczęć Państwowej Komisji Egzaminacyjnej dla Rzemiosła w Poznaniu (APP, Tłoki, sygn. T X, 151), pieczęć komisarza okręgowego dla Wielkopolski/Poznania (APP, Tłoki, sygn. T XI, 5), pieczęć kościoła parafialnego w Wilkowyjach (Archiwum Archidiecezjalne w Gnieźnie [dalej: AAG], sygn. S 53), pieczęć kościoła parafialnego w Wągrowcu (AAG, sygn. S 72), pieczęć konsystorza generalnego archidiecezji gnieźnieńskiej (AAG, sygn. S 202), pieczęć parafii farnej w Gnieźnie (AAG, sygn. S 274), pieczęć dozoru kościelnego w Kruszwicy (AAG, sygn. S 308), pieczęć cechu piekarzy w Stęszewie (Muzeum Regionalne w Stęszewie [dalej: MR Stęszew], sygn. MRSt 72), pieczęć sygnetową z herbem Prawdzic (Muzeum Mazowieckie w Płocku, sygn. MMP/S/8291) oraz pieczęć z inicjałami „N. S. G.” (zbiory prywatne autorów). Zob. Zbiór tłoków i stempli pieczętnych w zasobie Archiwum Państwowego w Poznaniu, oprac. M. Górny, M. Hlebionek i in., pod red. P. Pokory, przy współpracy M. Hlebionka, tłum. E. Jiya, D. Młodzianowska-Pilczuk, Poznań 2015, nr kat. 24, 38, 49, 72, 363, 625, 722; E. Popiołek, Tłoki pieczętne w zbiorach płockich, Płock 1983, nr kat. 29; K. Okoniewska, Zbiór tłoków i stempli pieczętnych w Archiwum Archidiecezjalnym w Gnieźnie. Komunikat z V Sesji Mecenatu Skarbów Stowa (12.06.2017 r.), „Studia Gnesnensia" 2017, t. 31, s. 350.

${ }^{33}$ E. Majkowski, Fryderyk Wilhelm Below: pieczętarz..., s. 323-341; Pamiatkowy Kalendarz Przemystowy wydany staraniem Towarzystwa Młodych Przemystowców w Poznaniu w dziesiata rocznice jego istnienia na rok przestępny 1884, s. 154 (w ogłoszeniu poznańskiego jubilera i złotnika, Michała Kudlińskiego, znalazła się informacja, że jego wyroby, takie jak: broszki, kolczyki, szpil- 
BELOW, Stefan Jakub (ur. 25 lipca 1857 r. w Poznaniu - zm. 7 lutego 1903 r. w Poznaniu) ${ }^{34}$. Grawer, który poszedł w ślady ojca i od najmłodszych lat uczył się rzeźby i rytownictwa. W latach 80. XIX w. uczęszczał do berlińskiej Akademii Sztuk Pięknych, gdzie pobierał lekcje malarstwa i rzeźby. W 1888 r. ożenił się z Walerią Magdaleną Tokarską. Mieli syna Stanisława. Po śmierci ojca w 1895 r. przejął pracownię grawerską, którą dalej z powodzeniem prowadził. Zmarł w lutym 1903 r., w wieku zaledwie 43 lat.

Znane są tylko nieliczne prace pieczętarskie i medalierskie Stefana Belowa ${ }^{35}$. Niemniej jednak w jednym z ogłoszeń tego wytwórcy, przedstawiono szeroką ofertę wykonywanych robót w metalu, kamieniach szlachetny, glinie, gumie, wosku itd. Podstawowymi usługami w jego zakładzie było: rytowanie (na wszelkich metalach, w tym srebrze i złocie), galwanizowanie (w złocie, srebrze i niklu) ${ }^{36}$, rysowanie (kredowe, ołówkowe i piórkowe), modelowanie (w wosku, glinie i plastelinie), oraz rzeźbienie i wytłaczanie $\mathrm{w}$ najrozmaitszych kruszcach ${ }^{37}$. W tym ogłoszeniu zamieszczono również informację o chęci przyjęcia uczniów „do gruntownego kształcenia się w rytownictwie” ${ }^{38}$.

CHRZANOWSKI, Czesław? (ur. 1 czerwca 1904 r. w Żninie) ${ }^{39}$. Ślusarz, który prowadził w latach 30. XX w. zakład rzemieślniczy przy ul. św. Marcin 4 w Poznaniu, w którym wykonywał m.in. pieczęcie kauczukowe ${ }^{40}$.

CHWINOWS KI, K. (Poznań). Prowadził na początku lat 30. XX w. fabrykę pieczęci przy ul. Strzeleckiej $14 \mathrm{w}$ Poznaniu ${ }^{41}$.

ki do krawatu, guziki do mankietów, medale ze złota i srebra, zostały ozdobione reliefowym popiersiem króla Jana III Sobieskiego, które wykonał i sygnował Below).

${ }^{34}$ APP, AmP - Kartoteka, sygn. 14270, k. 551.

${ }^{35}$ E. Majkowski, Fryderyk Wilhelm Below: pieczętarz..., s. 341-346; J. Strzałkowski, Stownik medalierów..., s. 26.

${ }^{36}$ Galwanizowanie - powlekanie wyrobów metalowych warstwą innego metalu za pomocą elektrolizy. Stosuje się je dla ochrony przedmiotów lub ich upiększenia, np. „drut poddaje się cynkowaniu w celu zabezpieczenia go przed rdzewieniem. Biżuterię sztuczną pozłaca się, aby nadać jej wygląd prawdziwej", cyt. za: C. Streubel, Grawerstwo, Warszawa 1959, s. 185.

${ }^{37}$ Kalendarz Przemysłowy na Rok Pański 1891, Poznań 1891, s. 145.

38 Tamże.

${ }^{39}$ Jego rodzicami byli: Franciszek i Antonina z d. Kabacińska. 24 kwietnia 1931 r. ożenił się z Władysławą z d. Duszyńską, ur. 22 lutego 1907 r., z którą miał córkę Michalinę. Od 1927 r. małżonkowie mieszkali przy ul. Wierzbięcice $13 \mathrm{w}$ Poznaniu, a od $1931 \mathrm{r}$. w budynku przy ul. Bosej 4 m. 18, zob. APP, AmP - Kartoteka, sygn. 14328, k. 219.

40 "Nowy Kurjer" z 2 maja 1930, r. 41, nr 102, nr ogłoszenia 2138.

${ }^{41}$ Księga Adresowa Polski (wraz z w. m. Gdańskiem) dla handlu, przemystu, rzemiost i rolnictwa 1930, s. 1398. 
DMOCHOWSKI, Feliks (ur. 18 maja 1812 r. w Cedrach pod Stawiskami ${ }^{42}$ zm. 20 kwietnia 1892 r. w Inowrocławiu) ${ }^{43}$. Grawer, pieczętarz i ilustrator. Jako jeden z pierwszych rzemieślników wziął udział w powstaniu listopadowym w Warszawie i walczył do jego zakończenia ${ }^{44}$. Służył w III Lekkiej Artylerii pod dowództwem gen. Józefa Bema, będąc w randzie podporucznika. Miał odznaczyć się męstwem w bitwie pod Wolą, za co jego przełożony udekorował go srebrnym krzyżem Orderu Virtuti Militari ${ }^{45}$. Po klęsce powstania przeniósł się do Poznania, gdzie mieszkał i pracował jako kupiec i rytownik przez ponad dwadzieścia lat. Przypuszczalnie w połowie lat 60 . XIX w. przeniósł się do Gniezna, gdzie żył i przebywał do co najmniej $1880 \mathrm{r}$. Dmochowski wziął także udział w 1868 r. w zjeździe weteranów powstania listopadowego, które miało miejsce w poznańskim Bazarze ${ }^{46}$.

W poznańskich księgach adresowych odnotowano miejsca jego zamieszkania, znajdujące się przy Neue Straße 5 (w latach 1855-1862; obecnie ul. Ignacego Paderewskiego) ${ }^{47}$ i 5 a (w latach $\left.1862-1868\right)^{48}$, a także przy tej samej ulicy pod numerem 3 (od około $1868 \mathrm{r}$.) ${ }^{49}$. Na podstawie wzmianek z tychże ksiąg dowiadujemy się również, jakich Feliks Dmochowski podejmował się zajęć i prac zarobkowych. Poza działalnością grawersko-pieczętarską (Petschaftstecher) ${ }^{50}$,

${ }^{42}$ Właśc. Cędry-złotystok, zob. Stownik geograficzny Królestwa Polskiego i innych krajów stowiańskich, t. 1, s. 537.

43 "Goniec Wielkopolski” z 12 grudnia 1880, r. 4, nr 285, s. 2; "Dziennik Poznański" z 22 kwietnia 1892, r. 34, nr 92, s. 5 (nekrolog). W poznańskich księgach adresowych zapisywano imię i nazwisko F. Dmochowskiego w paru wariantach: Felix Dmochowski, Felix Dmóchowski lub Feliks Dmóchowski.

44 "Goniec Wielkopolski” z 12 grudnia 1880, r. 4, nr 285, s. 2.

45 Tamże.

${ }^{46}$ W Muzeum Historii Miasta Poznania [dalej: MHMP] znajduje się fotografia uczestników zjazdu weteranów powstania 1831 r., którą wykonano 26 czerwca 1868 r. na dziedzińcu Bazaru poznańskiego (MHMP, sygn. MNP/D/183b). Pod fotografią uczestnicy zjazdu zamieścili swoje podpisy, wśród których znajduje się autograf Feliksa Dmochowskiego. Ostatnio reprodukcję tej fotografii opublikowała A. Murawska, Seweryn Mielżyński. Szkic do portretu dobrze zastużonego, [w:] Seweryn Mielżyński 1804-1872, oprac. K. Gieszczyńska-Nowacka, T.I. Grabski, M.P. Michałowski, A. Murawska, E. Siejkowska-Askutja, Poznań 2018, il. 12.

${ }^{47}$ Posener Wohnungs-Anzeiger auf das Jahr 1855, s. 15.

${ }^{48}$ Tamże, 1865, s. 17.

${ }^{49}$ Tamże, 1868, s. 10.

50 Typariusze wykonane przez Feliksa Dmochowskiego: pieczęć dominium Czechy (MNRiPR-S, sygn. MNR H-481), pieczęć cechu blacharzy we Wrześni (Muzeum Regionalne im. Dzieci Wrzesińskich we Wrześni [dalej: MR Września], sygn. MRW 128), pieczęć parafii pw. św. Trójcy w Skarboszewie (AAG, sygn. S 36), pieczęć dekanatu Rogowo (AAG, sygn. S 37), pieczęć parafii pw. św. Marcina w Kuczkowie (AAG, sygn. S 58), pieczęć cechu krawców w Czerniejewie (APP, Tłoki, sygn. T X, 23), pieczęć cechu łącznego w Gnieźnie (APP, Tłoki, sygn. T X, 34). Zob. także Zbiór tłoków i stempli pieczętnych..., nr kat. 497, 508; K. Okoniewska, Najstynniejsi poznańscy wytwórcy pieczęci, http://ehistoria.edu.pl/main/articles/show/article:Najsłynniejsi-poznanscy-wytworcy-pieczeci-120/ (dostęp: 14.09.2018); tejże, Zbiór tłoków i stempli pieczętnych..., s. 350. 


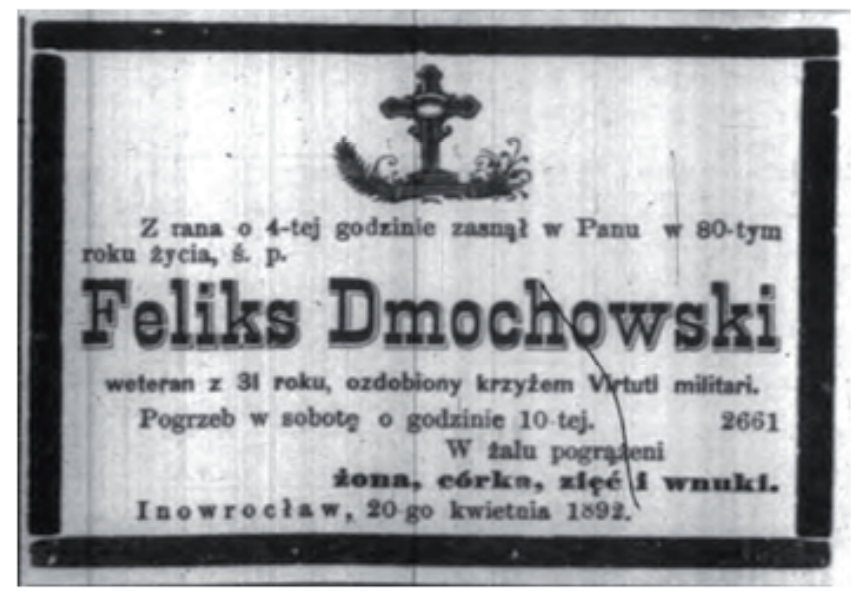

Il. 1. Nekrolog Feliksa Dmochowskiego.

Źródło: „Dziennik Poznański” z 22 kwietnia 1892, r. 34, nr 92, s. 5.

zajmował się też kupiectwem ${ }^{51}$, prowadził herbaciarnię (Theeniederl) ${ }^{52}$, handlował galanterią i biżuterią (Bijouterie- und Galanterie-Handlung) ${ }^{53}$, oraz produkował i sprzedawał sztuczne kwiaty (Blumenfabrikant) ${ }^{54}$. Znamy także jego realizacje litograficzne ${ }^{55}$ oraz ilustratorskie ${ }^{56}$.

W książce Polityczna działalność rzemiosta wielkopolskiego w okresie zaborów 1793-1918 odnotowano, że poznański rzemieślnik-grawer Dmochowski wykonywał patriotyczne i religijne wizerunki, które noszono podczas ważnych uroczystości ${ }^{57}$. W artykule ks. Edmunda Majkowskiego, dotyczącego innego poznańskiego pieczętarza - Fryderyka W. Belowa, błędnie przyda-

${ }^{51}$ Posener Wohnungs-Anzeiger auf das Jahr 1862, s. 15.

52 Tamże.

53 Tamże.

54 Tamże, 1855, s. 15.

${ }^{55}$ Jana Łaskiego, arcybiskupa gnieźnieńskiego, prymasa, legata urodzonego Liber beneficiorum archidyecezyi gnieźnieńskiej z poręki Towarzystwa Przyjaciót Nauk Poznańskiego podtug kodeksów rękopiśmiennych archiwum gnieźnieńskiego i kaliskiego. T. 2, Obejmujący Archidyakonaty: Kaliski, Wieluński, Łowicki $i$ Łęczycki, oprac. J. Łukomski, Gniezno 1881. Do tego wydania dołączono mapę archidiecezji gnieźnieńskiej z 1880 r., którą podług wzoru Jana Łukomskiego wyrytował na kamieniu (litografia) Feliks Dmochowski. Napis w prawym dolnym rogu mapy: „Rytował na kamieniu Feliks Dmochowski - w Gnieźnie".

${ }^{56}$ A. Hinc, „Na waszym grobie, waleczni kosarze...": motyw kosyniera w poznańskiej Wiośnie Ludów, KMP 2008, nr 1, s. 306-314. W artykule zreprodukowano wykonane przez Dmochowskiego ilustracje do czasopisma "Gazeta Wielkopolska Niedzielna", ale niestety nie odnotowano ich autorstwa, pomimo tego, że sygnatura „F. Dmochowski” jest wyraźnie widoczna na załączonych reprodukcjach.

${ }^{57}$ Polityczna działalność rzemiosła wielkopolskiego w okresie zaborów (1793-1918), oprac. T. Filipiak i in., Poznań 1963, s. 328. 
no Dmochowskiemu imię Franciszek ${ }^{58}$. Jego osobę wymienia E. Majkowski z tego względu, że Feliks był wykonawcą nowych pieczęci dla archidiecezji gnieźnieńskiej i poznańskiej ${ }^{59}$.

EHLERT, Johann Gustav (ur. 12 czerwca 1833 r. w Pobiedziskach zm. 11 listopada 1908 r. w Poznaniu) ${ }^{60}$. Grawer, który był żonaty z Anną, ur. 2 sierpnia 1852 r. w Poznaniu ${ }^{61}$. W tym też mieście Ehlert zamieszkiwał w wielu miejscach, były to następujące adresy: Wrocławska 15 (około 1862$1865)^{62}$ i później także pod numerem 32 (około 1865-1883) ${ }^{63}$, Podgórna 13 (w latach 1883-1889) ${ }^{64}$, pl. Wolności 1 (w latach 1889-1893) ${ }^{65}$, Podgórna 6 (w latach 1893-1895) ${ }^{66}$, pl. Wolności 17a (w latach 1895-1897) ${ }^{67}$ i później pod numerem 15 (w latach 1897-1898) ${ }^{68}$, Rycerska 38 (w latach 1898-1899) ${ }^{69}$ oraz ponownie ul. Wrocławska 13/14 (w latach 1899-1902) ${ }^{70}$.

W paru odnalezionych ogłoszeniach znalazła się informacja, że Ehlert nie tylko wykonywał pieczęcie, ale także handlował papierem ${ }^{71}$. Natomiast w anonsie umieszczonym w „Dzienniku Poznańskim” z roku $1874^{72}$ oraz spisach mieszkańców Poznania z 1862 i $1865 \mathrm{r} .{ }^{73}$ pojawiają się osoby o tym samym nazwisku, lecz o innych imionach - Julius Ehlert (jubiler i złotnik) oraz Johann August Ehlert (najpewniej błąd w zapisie drugiego imienia). Na tym etapie badań nie sposób ustalić, czy wymienione osoby pochodziły z jednej rodziny, czy też zbieżność nazwisk jest przypadkowa.

\footnotetext{
${ }^{58}$ E. Majkowski, Fryderyk Wilhelm Below: pieczętarz..., s. 273.

${ }^{59} \mathrm{~W}$ ramach reform wprowadzanych przez abp. Leona Przyłuskiego w połowie XIX w., zob. tamże, s. 273-274 i 291-297.

${ }^{60}$ APP, AmP - Ewidencja ludności, sygn. 14380, k. 827-828.

${ }^{61}$ Zmarła 27 stycznia 1923 r., zob. tamże.

${ }^{62}$ Posener Wohnungs-Anzeiger auf das Jahr 1862, s. 16.

${ }^{63}$ Tamże, 1865, s. 19; tamże, 1868, s. 11; Adressbuch für die Stadt Posen 1872, s. 36; tamże, 1876, s. 16.

${ }^{64}$ Adress- und Geschäfts-Handbuch der Stadt Posen 1885, s. 18; tamże, 1890, s. 24.

65 Tamże, 1890, s. 24.

${ }^{66}$ Adress- und Geschäfts-Handbuch der Stadt Posen nebst der vororte Bartholdshof, Berdychowo, Jersitz, St. Lazarus, Pietrowo und Wilda 1894, s. 25; tamże, 1895, s. 28.

${ }^{67}$ Tamże, 1896, s. 35.

${ }^{68}$ Adress- und Geschäfts-Handbuch der Stadt Posen sowie der Vororte Bartholdshof, Jersitz, St. Lazarus und Wilda 1898, s. 39.

${ }^{69}$ Adress- und Geschäfts-Handbuch der Stadt Posen sowie der Vororte Jersitz, St. Lazarus und Wilda 1899, s. 42.

70 APP, AmP - Kartoteka, sygn. 14380, k. 828.

${ }^{71}$ „Wielkopolanin” z 20 lutego 1884, r. 2, nr 15, s. 4; „Wielkopolanin” z 13 grudnia 1884, r. 2 , nr 100, s. 4.

72 „Dziennik Poznański” z 25 lipca 1874, r. 16, nr 167, s. 4.

${ }^{73}$ Posener Wohnungs-Anzeiger auf das Jahr 1862, s. 16; tamże, 1865, s. 19. W spisie z 1868 r. zapisano poprawnie imiona i nazwisko Johanna Gustava Ehlerta, por. tamże, 1868, s. 11.
} 
Typariusze pieczętne sygnowane przez J.G. Ehlerta występują stosunkowo często w wielkopolskich archiwach i muzeach ${ }^{74}$. Są to najczęściej pruskie pieczęcie urzędowe, które charakteryzują się postacią jedynie tekstową, tzw. pieczęć amorficzna ${ }^{75}$. Ich napis napieczętny jest otokowy, w polu pieczęci zaś w dwóch wierszach, majuskułowy w języku niemieckim. Wykonanie części z odnalezionych typariuszy przypada na lata 1887-1918, kiedy podjęto się realizacji ustawy wprowadzającej czterdzieści powiatów w prowincji poznańskiej, w skład której weszło m.in. podzielenie powiatu poznańskiego na dwa nowe powiaty (Poznań Wschód i Poznań Zachód) oraz wydzielenie miasta Poznań jako powiat miejski ${ }^{76}$.

ELKELES, Salomon (Poznań). Był właścicielem zakładu pieczętarskiego i biura technicznego, które w latach 80. XIX w. działały w Poznaniu. Ich siedziba znajdowała się najpierw przy ul. Mokrej $1^{77}$, a następnie pod numerem $2^{78}$. Przedsiębiorstwo Elkelesa nie działało długo, albowiem w księdze adresowej z 1886 r. odnajdziemy Salo z przypisanym zawodem jedynie jako kupiec (Kaufmann $)^{79}$, a w spisie z 1890 r. jest już przedstawiany jako pomocnik $\mathrm{w}$ teatrze (Theater-Requisiteur) ${ }^{80}$.

Salomon Elkeles w anonsach prasowych oferował: klisze do ogłoszeń, stemple, stemple mosiężne $\mathrm{z}$ farbą ${ }^{81}$, eleganckie niklowane stemple kieszonkowe ${ }^{82}$,

${ }^{74}$ Udało się do tej pory odnaleźć następujące typariusze wykonane przez Ehlerta: pieczęć urzędu sołeckiego w Nowej Wsi Królewskiej (APP, Tłoki, sygn. T V, 25), pieczęć zarządu majątku w Trzciance (APP, Tłoki, sygn. T V, 40), pieczęć wójta wiejskiego w Lesznie (APP, Tłoki, sygn. T IX, 99), pieczęć urzędu stanu cywilnego we Wrześni (MR Września, sygn. MRW 2098), pieczęć zarządcy dóbr Góry (MR Września, sygn. MRW 2227), pieczęć zarządu dóbr Stare Gałęzewo (MR Września, sygn. MRW 2225), pieczęć zarządcy dóbr Nowa Wieś Królewska (MR Września, sygn. MRW 2224), pieczęć cechu młynarzy w Stęszewie (MR Stęszew, sygn. MRSt 73), pieczęć wójta wiejskiego w Napachaniu (MNRiPR-S, sygn. MNR H-1153), pieczęć wójta wiejskiego w Wirach (MNRiPR-S, MNR H-1154). Zob. także Zbiór tłoków i stempli pieczętnych..., nr kat. 98, 113, 282.

75 „Pieczęć amorficzna - pieczęć bez wyraźnej legendy i zaznaczonych granic pola, głównie współczesne tuszowe pieczęcie tekstowe", cyt. za: A. Baniecki, D. Bednarek, D. Żygadło, R. Forysiak-Wójciński, P. Gut, J. Leśniewska, M. Hlebionek, Materiaty do polskiego stownika sfragistycznego, "Archiwista Polski” 2010, t. 3, s. 51.

${ }^{76}$ J. Kozłowski, Administracja Wielkopolski pod pruskim zaborem 1793-1918, Poznań 2000, s. 60-64.

77 "Wielkopolanin” z 10 marca 1883, r. 1, nr 20, s. 4.

78 "Wielkopolanin" z 11 sierpnia 1883, r. 1, nr 64, s. 4.

${ }^{79}$ Adressbuch der Stadt Posen 1886, s. 20.

${ }^{80}$ Adress- und Geschäfts-Handbuch der Stadt Posen 1890, s. 25. Salomon mieszkał wtedy przy ul. Żydowskiej 10.

${ }^{81}$ Pieczęcie umieszczane $\mathrm{w}$ prostokątnych mosiężnych pudełkach, w których wpierw wmontowywano poduszkę nawilżoną farbą bądź tuszem.

82 Pieczęcie umieszczane w niklowanych okrągłych pudełkach, które przypominały zegarki kieszonkowe, stąd wzięła się ich niemiecka nazwa: Uhrstempel. 
stemple do medalionów ${ }^{83}$, breloki oraz wszelkie roboty i artykuły wchodzące w zakres jego fachu, czyli grawerstwa ${ }^{84}$.

HÜBSCH, Mar (Wrocław). Właściciel fabryki pieczęci kauczukowych, która na początku XX w. znajdowała się na Hintermarkt 97 (obecnie ul. Kurzy Targ) we Wrocławiu. W tym czasie firma prowadzona przez Mara Hübscha ogłaszała się w poznańskiej prasie ${ }^{85}$, oferując w swym anonsie oprócz wyrobu pieczęci, także wszelkie druki, szablony, medaliony oraz sprzedaż portmonetek $^{86}$.

INSTYTUT HERALDYCZNY "GRYF” (Poznań). Na początku XX w. mieścił się przy ul. Wielkie Garbary 48 w Poznaniu ${ }^{87}$. Przedsiębiorstwo przyjmowało zlecenia na wyrób takich przedmiotów, jak: tłoki pieczętne, karty wizytowe $\mathrm{z}$ herbami, herby rodzinne $\mathrm{z}$ masy sztucznej na elewacje dworów (,z masy sztucznej w rodzaj piaskowca") oraz malowane na płótnie, papierze lub szkle ${ }^{88}$. Instytut oferował także swe usługi w poszukiwaniu rodziny i jej zestawianiu w wywód genealogiczny, oraz udzielał wszelkich innych informacji z dziedziny heraldyki ${ }^{89}$.

JASZEWSKI, Leon (ur. 11 lutego 1885 r. w Wętfiu pod Kościerzyną) $)^{90}$. Od 1906 r. był zameldowany w Grudziądzu, następnie w Krakowie, po czym w 1915 r. przeprowadził się do Hohenelse obok Rheinsbergu w Niemczech, by ponownie powrócić do Grudziądza pod koniec tego roku ${ }^{91}$. Ostatnim miejscem zamieszkania Leona był Poznań, w którym od 1932 r. był zameldowany przy pl. Bernardyńskim 1 m. $15^{92}$.

L. Jaszewski prowadził zakład rytowniczo-pieczętarski w Poznaniu, który na początku lat 30. XX w. znajdował się przy ul. Strzeleckiej $32^{93}$.

83 Pieczęcie umieszczane w metalowych prostokątnych pudełkach, które montowano w stelaż tworzący kabłąk (dzięki czemu pudełko mogło się obracać), u góry zaś umieszczano kółko na łańcuszek lub rzemień. Na samym pudełku opracowywano grawerunek w formie np. portretu an face, popiersia, ornamentu, monogramu, symbolu czy też znaku korporacji rzemieślniczej.

${ }^{84}$ „Wielkopolanin” z 10 marca 1883, r. 1, nr 20, s. 4; „Wielkopolanin” z 11 sierpnia 1883, r. 1, nr 64, s. 4 .

85 „Posener Tageblatt” z 12 marca 1899, Jg. 38, nr 121, s. 12; „Posener Tageblatt” z 30 kwietnia 1899, Jg. 38, nr 201, s. 12.

86 Tamże.

${ }^{87}$ Adressbuch der Provinzial-Hauptstadt Posen 1908, s. 11.

${ }^{88}$ Tamże; „Łowiec Wielkopolski” z 1 września 1907, r. 1, nr 11, s. 178 nlb.

${ }^{89}$ Tamże.

90 APP, AmP - Ewidencja ludności, sygn. 14547, k. 25.

${ }^{91}$ Tamże, k. 25-26.

${ }^{92}$ Tamże, k. 26.

${ }^{93}$ Księga Adresowa Miasta Stołecznego Poznania na rok 1930, Dział Branż i Zawodów, s. LVII. 
JÓŹWI AK, I. (Poznań). Prowadził na początku lat 30. XX w. fabrykę pieczęci przy ul. Wierzbięcice $15 \mathrm{w}$ Poznaniu ${ }^{94}$.

KAISER, Theodor (Berlin). Właściciel berlińskiej fabryki pieczęci, którą założył w 1882 r. Siedziba firmy mieściła się w Berlinie w części południowo-zachodniej (Südwesten), przy następujących adresach: Friedrich Straße 47, Charlotten Straße 16 i także na rogu ulic Charlotten Straße 15a i Zimmer Straße 16.

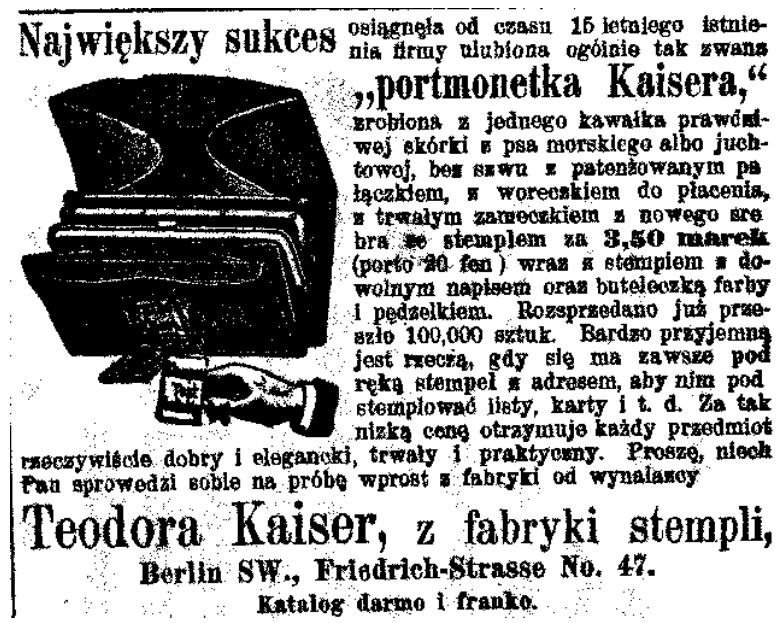

Il. 2. Ogłoszenie berlińskiej fabryki stempli Theodora Kaisera, w którym promuje skórzane portmonetki ze stempelkiem.

Źródło: „Wielkopolanin” z 18 kwietnia 1897, r. 15, nr 89, s. 7.

Pod koniec XIX w. berlińska firma ogłaszała się w prasie poznańskiej ${ }^{95}$, w której oferowała czytelnikom: mechaniczne aparaty do stemplowania ${ }^{96}$, stemple metalowe, szyldy, maszyny do paginowania ${ }^{97}$ oraz jako specjalność firmy - portmonetki ze stemplem ${ }^{98}$.

${ }^{94}$ Księga Adresowa Polski (wraz z w. m. Gdańskiem) dla handlu, przemystu, rzemiost i rolnictwa 1930, s. 1398.

95 „Wielkopolanin” z 18 kwietnia 1897, r. 15, nr 89, s. 7.

${ }^{96}$ Maszyny wyposażone $\mathrm{w}$ mechanizm sprężynowy, wykonane przeważnie ze stali, automatycznie odbijające ciągle tę samą treść. Były zbudowane z uchwytu drewnianego lub metalowego w formie gałki lub prostej, mechanizmu sprężynowego (wbudowany w szyjce i uchwycie maszyny) i matrycy obrotowej, na której umieszczano płytkę z wygrawerowaną treścią właściciela pieczęci (np. faksymile podpisu).

${ }^{97}$ Maszyny wyposażone w mechanizm sprężynowy, wykonane najczęściej ze stali. Służyły do numerowania i paginowania kart, automatycznie odbijały jeden numer 2, 3 i 4 razy albo ciągle jeden i ten sam - zmiana numeru zachodziła na ostatniej taśmie, kiedy zmieniał się mechanizm odbicia, czyli po jego wcześniejszym dociśnięciu mechanizm automatycznie przeskakiwał. Maszyny te znacząco usprawniały pracę w biurach i kancelariach. Były zbudowane z uchwy- 
KAPELA, Ludwik (ur. 12 sierpnia 1865 r. w Trzemesznie - zm. 13 października 1930 r. w Poznaniu) ${ }^{99}$. Pierwszą żoną Ludwika była Leokadia z d. Burkiewicz (1851-1921) ${ }^{100}$, z którą miał troje dzieci: Julię, Bolesława i Mariana ${ }^{101}$. W 1921 r. zmarła Leokadia, która była od Ludwika o czternaście lat starsza. Po dwóch latach od śmierci pierwszej żony Ludwik ożenił się po raz drugi, żeniąc się 10 lutego 1923 r. z Martą Dymarską (ur. w 1872 r.) $)^{102}$. Drugie małżeństwo nie trwało jednak długo, ponieważ niebawem po ślubie mąż doznał wylewu krwi do mózgu i małżonkowie przestali mieszkać razem. Ostatnie lata życia Ludwik spędził pod opieką pielęgniarza w domu na Sołaczu ${ }^{103}$. Ludwik Kapela ostatecznie zmarł w 1930 r. po paru latach przebytej choroby.

Swoją drogę zawodową rozpoczął od nauki zawodu w drukarni Gustava Olawskiego w Trzemiesznie ${ }^{104}$, gdzie wpierw uzyskał także podstawowe wykształcenie. Po trzech latach został czeladnikiem. Po odbyciu służby wojskowej w armii pruskiej trafił na krótki czas do Wągrowca, gdzie pracował jako zecer. W 1898 r. przeniósł się do Poznania i tam otworzył drukarnię przy ul. Gołębiej $6^{105}$. Początkowo pracował z jednym uczniem, lecz gdy drukarnia zaczęła się rozrastać, przeniósł zakład w 1901 r. na ul. Wrocławską 9 (niedaleko poprzedniej lokalizacji) i przyjął dodatkowego ucznia ${ }^{106}$. W latach 1902-1904

tu drewnianego w formie gałki lub prostej, mechanizmu sprężynowego (wbudowany w szyjce i uchwycie) i matryc obrotowych, na których umieszczano numery od 1 do 9 . W zależności od liczby kółek z numerami, tworzących rząd-serie, tyle maksymalnie można było oznaczyć dokumentów. Występowały różne wielkości czcionek.

${ }_{98}^{8}$ Skórzane portmonetki, które na jednym z boków mają zamontowane stalowe prostokątne pudełko (wewnątrz wykończone materiałem nawilżonym tuszem) z wyjmowanym stempelkiem osadzonym na płaskiej blaszce.

99 APP, AmP - Kartoteka, sygn. 14582, k. 316. Zob. także nekrologi i wspomnienia: „Kurier Poznański” z 14 października 1930, r. 25, nr 474, s. 6; „Kurier Poznański” z 15 października 1930, r. 25, nr 476, s. 9.

${ }^{100}$ APP, AmP - Kartoteka, sygn. 14582, k. 316.

101 Tamże, k. 316-317.

102 Tamże.

${ }^{103}$ Więcej o willi Kapelów na poznańskim Sołaczu zob. P. Korduba, Sołacz: domy i ludzie, Poznań 2012, s. 254-259.

${ }^{104}$ Gustav Olawski (1810-1889) - drukarz, księgarz i wydawca m.in. sprawozdań Królewskiego Katolickiego Gimnazjum w Trzemesznie, które ukazywały się w drugiej połowie XIX w. W tym czasie Olawski prowadził drukarnię mieszczącą się w rynku w Trzemesznie. Po jego śmierci w 1889 r. drukarnię przejął L. Marten.

105 Zob. m.in. „Kurier Poznański” z 13 października 1908, r. 3, nr 235, s. 8; „Przemysłowiec”. Tygodnik dla polskiego rzemiosła, przemysłu i handlu z 22 października 1911, r. 8, nr 43, s. 8; „Posener Tageblatt” z 11 października 1908, Jg. 47, nr 479, s. 6; Deutsches Reichs-Adressbuch für Industrie, Gewerbe, Handel 1920, Bd. 2, s. 1578 i 4193.

${ }^{106} \mathrm{Z}$ tego czasu, kiedy Ludwik Kapela zaczął działać pod nowym adresem przy ul. Wrocławskiej 9, zachował się dwustronicowy druk reklamowy z wzorami pieczęci wyjętymi z głównego katalogu, które firma kolportowała jako ulotki (MHMP, sygn. MNP D 3965). Z później- 
drukował m.in. „Gazetę Ludową” redagowaną przez Różę Luksemburg. Po tym czasie Ludwik otworzył także wytwórnię pieczęci, co wymusiło kolejną przeprowadzkę całej firmy na ul. Wrocławską 18. Zakład pod tym adresem mieścił się do roku $19399^{107}$. W drugiej połowie lat 20. XX w. firma prowadziła także swoją filię przy ul. Gdańskiej 37 w Bydgoszczy ${ }^{108}$.

W 1908 r. Kapela wziął udział w Wystawie Przemysłowej w Poznaniu109, na której otrzymał srebrny medal za wyroby pieczętarskie i druki reklamowe ${ }^{110}$. Ludwik był także członkiem Związku Zakładów Graficznych i Wydawniczych Polski Zachodniej.

Ludwik Kapela był z zawodu drukarzem, toteż głównym przedmiotem działalności jego firmy było drukarstwo ${ }^{111}$. Niemniej firma należąca do niego, później prowadzona także przez jego syna Bolesława, działała równie prężnie w dziedzinie wytwórstwa pieczęci. Świadczyć o tym może choćby to, iż

szego okresu, gdy prowadzono działalność przy Wrocławskiej 18, zachował się np. rachunek wystawiony 4 kwietnia 1938 r. na jedną pieczęć przez fabrykę stempli Bolesława Kapeli (nadal jednak pod nazwą „L. Kapela”) dla Władysława[?] Gadowskiego (MHMP, sygn. MNP D 11.354). Zob. także „Ziemianin”. Tygodnik naukowo-rolniczy i ekonomiczny z 27 kwietnia 1912, r. 63, nr 17, s. 108 nlb; „Orędownik”. Najstarsze ludowe pismo narodowe i katolickie w Wielkopolsce z 31 sierpnia 1913, r. 43, nr 200, s. 8.

107 Dane biograficzne o Ludwiku Kapeli i informacje na temat jego przedsiębiorstwa przybliżono na podstawie następującej literatury: J. Jachowski, Ludwik Kapela, [w:] Polski stownik biograficzny [dalej: PSB], t. 11, s. 626-627; tegoż, Kapela Ludwik i Bolestaw, [w:] Stownik pracowników książki polskiej, Warszawa-Łódź 1972, s. 395-396; J. Mulczyński, Rodzina Ludwika i Bolesława Kapelów na Sołaczu, KMP 1999, t. 67, nr 3, s. 232-248.

108 Spis Abonentów Sieci Telefonicznej Okreggu Dyrekcji Poczt i Telegrafów w Bydgoszczy: w marcu 1926 r., s. 268; Ksiażka Adresowa Miasta Bydgoszczy na rok 1928, s. 51.

109 Pamiętnik Wystawy Przemystowej w Poznaniu z roku 1908, Poznań 1909, s. 39.

110 „Przemysłowiec". Tygodnik dla rzemiosła, przemysłu i handlu z 18 lipca 1908, r. 5, nr 29, s. 230.

${ }^{111} \mathrm{~W}$ wyniku wstępnego przeglądu odnaleziono sporo różnych druków: książek, czasopism, gazet, ulotek, kart, rachunków i wiele tzw. drobnych druków. W związku z czym wymieniamy wybrane pozycje, które zrealizowała drukarnia Ludwika Kapeli, zob. m.in.: Sprawozdanie z czynności Katolickiego Towarzystwa Rzemieślników Polskich pod wezwaniem św. Józefa w Poznaniu z roku 1905, Poznań 1906; A. Piotrowski, 50 dni rząów Rady Robotników i Żotnierzy w Poznaniu, Poznań 1919; W. Pniewski, Akademja Poznańska. Szkic historyczny, Poznań 1919; H. Mniszek, Verte. Powieść: dwie części w jednym tomie, Poznań 1923 (wydanie trzecie); K. Rzepecki, Pułk Czwarty 1830-1831. Szkic historyczny wedtug relacji ustnej i pamiętnikarskich notatek Kajetana Wtadysława Rzepeckiego, Poznań 1923 (wydanie trzecie); M. Rościszewski, Pisarz i doradca. Podręcznik praktyczny dla osób nie obytych z piórem [...], Lwó-Poznań 1921; papier firmowy drogerii Józefa Czepczyńskiego (MHMP, sygn. MNP D 3173/1); rachunek drogerii J. Czepczyńskiego wystawiony 1 stycznia 1909 r. (MHMP, sygn. MNP D 3140/3); list pochwalny przyznany S. Leszczyńskiemu za piękną dekorację balkonową, wystawiony przez Poznańskie Towarzystwo Zawodowych Ogrodników (MHMP, sygn. MNP D 2258); ubezpieczenie na życie z Banku Wzajemnych Ubezpieczeń w Poznaniu (MHMP, sygn. MNP D 3472). 
typariusze sygnowane przez firmę „L. Kapela” spotykamy często w wielkopolskich instytucjach muzealno-archiwalnych ${ }^{112}$.

KAPELA, Bolesław (ur. 7 lipca 1891 r. w Wągrowcu - zm. 31 grudnia 1942 r. w obozie Mauthausen-Gusen) ${ }^{113}$. Żoną Bolesława Kapeli była Zofia z d. Szews, pochodząca z Mąkowarska niedaleko Bydgoszczy. Pobrali się w 1920 r. w Poznaniu. Z tego małżeństwa urodziło się pięć córek: Czesława, Krystyna, Aleksandra, Eugenia i Gabriela ${ }^{114}$.

Po ukończeniu szkoły średniej poszedł w ślady ojca - wyuczył się zawodu drukarza i stemplarza. W 1912 r. wyjechał do Berlina w celu pogłębienia znajomości swojego fachu. W czasie I wojny światowej został wcielony do armii pruskiej. Po zakończeniu wojny wziął udział w powstaniu wielkopolskim ${ }^{115}$. Natomiast od 1919 r. począł samodzielnie kierować firmą założoną przez swojego ojca Ludwika Kapelę. Bolesław był ponadto założycielem i kierownikiem Wyższej Szkoły Graficznej w Poznaniu ${ }^{116}$, radnym miejskim oraz wieloletnim prezesem Związku Zawodowego Pracowników Poligraficznych.

Po I wojnie światowej firma prowadzona samodzielnie przez Bolesława zaczęła działać coraz prężniej i rozwijała się. Bolesław poza tym, że był dru-

112 Udało się odnaleźć kilkanaście typariuszy wykonanych przez firmę „L. Kapela”: pieczęć Stowarzyszenia Pań Miłosierdzia w Środzie (APP, Tłoki, sygn. T IV, 35), pieczęć pocztowa z napisem „wolne od opłaty stemplowej” (APP, Tłoki, sygn. T IX, 197), pieczęć Związku Niższych Pracowników Poczty Telegrafów i Telefonów w Środzie (APP, Tłoki, T IX, 227), pieczęć pomocnicza Związku Niższych Pracowników Poczty Telegrafów i Telefonów w Środzie (APP, Tłoki, T IX, 228), pieczęć Związku Sokołów Polskich - Dzielnica Wielkopolska w Środzie (APP, Tłoki, T IX, 238), pieczęć Koła Przyjaciół Harcerstwa w Środzie (APP, Tłoki, T IX, 249), pieczęć Czerwonego Krzyża w Środzie (APP, Tłoki, T IX, 251), pieczęć Towarzystwa Czytelni Ludowych w Środzie (APP, Tłoki, T IX, 253), pieczęć Towarzystwa Czytelni Ludowych w Środzie (APP, Tłoki, T IX, 254), pieczęć cechu młynarzy w Śmiglu (APP, Tłoki, sygn. T X, 172), pieczęć bractwa strzeleckiego w Środzie (APP, Tłoki, sygn. T X, 184), pieczęć cechu rzeźników w Trzemesznie (APP, Tłoki, sygn. T X, 194), pieczęć Towarzystwa Gimnastycznego „Sokół” w Stęszewie (MR Stęszew, sygn. MRSt 583), pieczęć cechu młynarzy w Stęszewie (MR Stęszew, sygn. MRSt 1554), pieczęć Dowództwa Dyonu Lotniczego (Wielkopolskie Muzeum Wojskowe, nr inw. WH 3073). Zob. Zbiór tłoków i stempli pieczętnych..., nr kat. 57, 380, 411, 432, 434, 436-437, 646, 658, 668; K. Okoniewska, Zbiór tłoków i stempli pieczętnych..., s. 351; Cenniejsze dary i nabytki Muzeum Narodowego w Poznaniu (1993-1994), "Studia Muzealne. Muzeum Narodowe w Poznaniu” 1994, z. 28, il. 88a-88b, s. 140 (w opracowaniu nie zidentyfikowano wykonawcy tłoka).

113 APP, AmP - Kartoteka, sygn. 14582, k. 317; J. Jachowski, Bolestaw Kapela, [w:] PSB, t. 11, s. 626; S. Bauman, P. Chrząszcz, Bolestaw Kapela (1891-1942), http://www.gedenkstaetten.at/ raum-dernamen/cms/index.php?id=4\&p=8311\&L=1 (dostęp: 6.08.2018).

114 J. Mulczyński, Rodzina Ludwika i Bolestawa..., s. 235-236.

115 Podobnie jak jego brat Marian, który został podporucznikiem w artylerii na mocy dekretu mianującego byłych sierżantów, podoficerów i urzędników byłej armii niemieckiej podporucznikami w Polskich Siłach Zbrojnych.

116 Zob. Wyższa Szkoła Graficzna w Poznaniu, Poznań [około 1930]. Druk ten udostępniła Biblioteka Raczyńskich w Poznaniu, zob. http://www.wbc.poznan.pl/dlibra/docmetadata? id=2196\&from=publication (dostęp: 1.06.2019). 


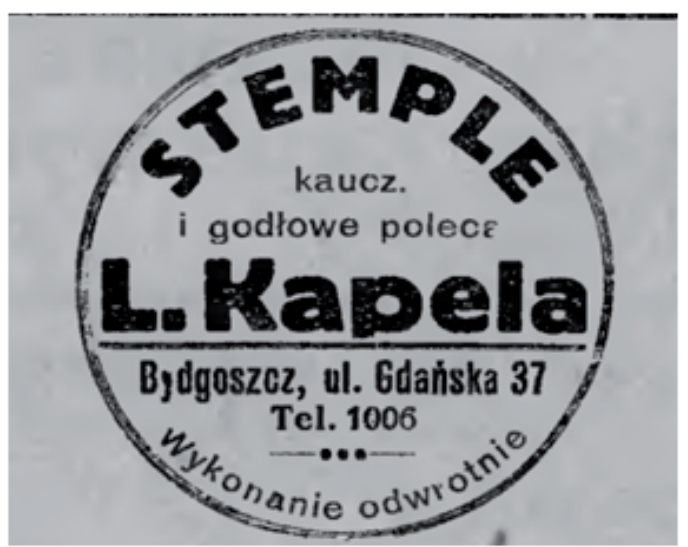

Il. 3. Ogłoszenie prasowe bydgoskiej filii firmy „L. Kapela” jako odcisk pieczętny. Źródło: Spis Abonentów Sieci Telefonicznej Okręgu Dyrekcji Poczt i Telegrafów w Bydgoszczy: w marcu 1926 r., s. 268.

karzem i właścicielem firmy, był także osobą wyróżniającą się charakterem. W relacjach o Bolesławie Kapeli mowa o jego uwielbieniu do muzyki i śpiewu. Swoją żonę poznał podczas I wojny światowej właśnie na konkursie śpiewaczym, który wtedy wygrał. Później, będąc znanym przedsiębiorcą w Poznaniu, do willi na Sołaczu bardzo często spraszał gości, z którymi biesiadował i muzykował. Organizował ponad to kiermasze, podczas których chodził z magnetofonem i zapraszał uczestniczących do siebie na piwo i kiełbasę. Wspierał młodych artystów i potrzebujących. Miał unikać samochodów, choć posiadał ich aż dwa. Sam zaś jeździł tramwajem. Poza tym zwraca się uwagę na jego pracowitość, albowiem wychodził do pracy na godz. 8.00 rano i pracował z przerwą na rodzinny obiad do godz. 22.00117.

Na podstawie spisów branż metalowych w "Roczniku Polskiego Przemysłu i Handlu" w latach 1932-1938 jesteśmy w stanie dowiedzieć się nieco więcej o zatrudnieniu oraz liczbie używanych maszyn i wykorzystywanej sile elektrycznej w zakładach Kapeli. W latach 1932-1934 firma „L. Kapela” zatrudniała 22 robotników i pięciu urzędników, wykorzystując cztery maszyny płaskie o mocy $20 \mathrm{HP}^{118}$. W latach 1936-1938 firma prawie podwoiła liczbę zatrudnionych robotników, ponieważ zatrudniała ich czterdziestu (liczba za-

117 Powyższe ustalenia biograficzne przybliżono ze wspomnień córki Bolesława Kapeli, Aleksandry Kubackiej z d. Kapela, zob. J. Mulczyński, Rodzina Ludwika i Bolestawa..., s. 232248.

118 „Rocznik Polskiego Przemysłu i Handlu” 1932, r. 3, poz. 4783; „Rocznik Polskiego Przemysłu i Handlu" 1934, r. 4, poz. 8883. HP (ang. horse power) - jednostka nazywana koniem parowym, czyli pozaukładowa jednostka mocy używana w krajach anglosaskich w XIX w., ale czasem także obecnie, dla porównywania mocy maszyn parowych z koniem. $\mathrm{W}$ pozostałych 
trudnionych urzędników, wykorzystanych maszyn i ich mocy pozostała bez zmian) $)^{119}$.

Zakład Ludwika Kapeli został w 1939 r. zarekwirowany przez Niemców i przekazany w administrację zastępczą Arnoldowi Bergowi ${ }^{120}$. Rodzinę Kapelów wysiedlono także z większej wilii na Sołaczu ${ }^{121}$, lecz po krótkim czasie udało im się powrócić i ukryć w budynkach gospodarczych, gdzie Bolesław zdołał jeszcze przed zarekwirowaniem całej firmy przenieść część maszyn ze stemplarni ${ }^{122}$. Mógł w związku z tym podrabiać przepustki do Generalnego Gubernatorstwa oraz drukować fałszywe kartki na żywność. $Z$ tego powodu 11 listopada 1940 r., w wyniku denuncjacji, Bolesław został aresztowany przez gestapo, wraz z żoną Zofią oraz trzema innymi mężczyznami znajdującymi się w ich domu ${ }^{123}$. Bolesław znalazł się w Forcie VII, gdzie był przesłuchiwany. Podczas procesu 13 czerwca 1941 r. został skazany na śmierć, lecz po rewizji wyrok zmieniono na dwanaście lat więzienia. W 1942 r. Bolesław został przewieziony do obozu koncentracyjnego w Mauthausen wraz z transportem 1130 więźniów politycznych ${ }^{124}$. W obozie został osadzony w trybie aresztu ochronnego (Schutzhaft). Przy rejestracji został nadany mu numer obozowy 18117, a w rubryce zawód wpisano: drukarz ${ }^{125}$. Trzy dni później, 15 grudnia 1942 r. Bolesław został przeniesiony do filii obozu Mauthausen-

krajach europejskich podobną jednostką jest koń mechaniczny, który dawniej także był nazywany koniem parowym.

119 „Rocznik Polskiego Przemysłu i Handlu” 1936, r. 5, poz. 9814; „Rocznik Polskiego Przemysłu i Handlu" 1938, r. 6, poz. 13359.

${ }^{120}$ W 1940 r. Urząd Powierniczy (Treuhandstelle) przekazał firmę „L. Kapela” w administrację zastępczą, dzięki czemu jej administratorem zastępczym (Kommissarischer Verwalter) mógł zostać Arnold Berg. Ostatnio na temat niemieckiej grabieży mienia w Kraju Warty pisał B. Rudawski, zob. B. Rudawski, Grabież mienia w Kraju Warty 1939-1945. Działalność Urzędu Powierniczego w Poznaniu, Poznań 2018.

W dokumentacji po firmie „L. Kapela”, prowadzonej w administracji zastępczej przez A. Berga, znajduje się m.in. korespondencja z kontrahentami, zamówienia, rachunki i potwierdzenia zapłaty, zob. APP, Urząd Powierniczy w Poznaniu [dalej: UPP], sygn. 13675. Zachował się także całoroczny bilans firmy z 1940 r., dzięki któremu możliwe jest zaobserwowanie np. poniesionych wydatków i strat lub prześledzenie cen wybranych produktów, zob. APP, UPP, sygn. 14004. Wymieniona dokumentacja z czasów okupacji niemieckiej zasługuje jednak na osobne opracowanie, tak zresztą jak historia firmy Ludwika i Bolesława Kapelów.

Z tego okresu, kiedy Arnold Berg prowadził skonfiskowaną przez Niemców stemplarnią, zachowało się kilka pieczęci „Namiestnik Rzeszy w Kraju Warty, Samorząd Okręgowy, Urząd do Spraw Genealogicznych" (APP, Tłoki, sygn. T IX, 198-202), zob. Zbiór tłoków i stempli pieczętnych..., nr kat. 381-385.

${ }^{121}$ APP, Centrala Przesiedleńcza w Poznaniu 1939-1940, sygn. 10, s. 294.

122 J. Mulczyński, Rodzina Ludwika i Bolestawa..., s. 245-246.

${ }^{123}$ Tamże, s. 246.

${ }^{124}$ KZ-Gedenkstätte Mauthausen - Mauthausen Memorial, sygn. AMM/Y/50, s. 312.

125 Tamże. 
-Gusen ${ }^{126}$. Ze względu na bardzo ciężkie warunki panujące w podobozie zmarł 30 grudnia 1942 r. Według księgi zgonów, śmierć nastąpiła o 7.30 rano w bloku nr 17 obozu Mauthausen. Jako przyczynę śmierci podano ropne zapalenie okrężnicy (Eitriger Dickdarmkatarrh) ${ }^{127}$ - trzeba jednak pamiętać, że w większości przypadków przyczyny śmierci więźniów fałszowano.

W 1948 r. Zofia Kapelowa starała się o uzyskanie listu żelaznego na prowadzenie przedsiębiorstwa rzemieślniczo-przemysłowego, który otrzyma$\mathrm{ła}^{128}$. Firmę odtąd prowadziła jedna z jej córek - Aleksandra. Niemniej jednak zakład zajmujący się wówczas wytwórstwem pieczęci nie utrzymał się i po pięciu latach firma została zlikwidowana ${ }^{129}$.

KIRSTEN, A. (Berlin). Właściciel fabryki stempli i zakładu rytowniczego, który znajdował się przy Dresdener Straße 128/129 w Berlinie w rejonie południowym (Südost). Na początku XX w. berlińska firma A. Kirstena ogłaszała się w prasie poznańskiej ${ }^{130}$.

Na podstawie jednego anonsu wiemy, że fabryka Kirstena wykonywała: pieczęcie metalowe i kauczukowe, szyldy metalowe (w żelazie, mosiądzu i koprowinie ${ }^{131}$ ), plombownice, numeratory, datowniki oraz prasy i praski do wytłaczania wypukłego ${ }^{132}$. Sprzedawano także niezbędne akcesoria do wykonywania odcisków pieczętnych (np. maczałki, czyli poduszki nasączone farbą, butelki z tuszem, lak w laskach, podstawki pod pieczątki, smary do maszyn itd. $)^{133}$.

KOMINOWS KI, Stefan (ur. 23 lipca 1895 r. w Poznaniu) ${ }^{134}$. Był z zawodu drukarzem. Jego żoną była Helena z d. Jankowiak, ur. 1 lutego 1893 r., z któ-

126 Tamże, sygn. AMM/Y/46a, nr dz. 5.

127 Tamże.

128 APP, Urząd Wojewódzki Poznański, sygn. 3158, s. 212-229.

129 J. Mulczyński, Rodzina Ludwika i Bolestawa..., s. 247-248.

130 „Praca” z 25 listopada 1900, r. 4, nr 48, s. 18.

131 Koprowina - inaczej miedź.

132 Maszyny wyposażone w dźwignię z mechanizmem hydraulicznym, wykonane $\mathrm{z}$ masywnego i ciężkiego metalu (najczęściej żeliwo). Służyły do pieczętowania na sucho, tj. bez użycia tuszu bądź laku, a jednocześnie odciskając pieczęć wypukle, albowiem dolna płytka matrycy ryta była negatywowo i wypukle, a górna wklęśle w pozytywie, co w wyniku użycia siły powodowało odciśnięcie wypukłej pieczęci suchej np. na papierze. Bywały mniejsze praski wyposażone w mechanizm sprężynowy oraz większe prasy do wytłaczania wypukłego. Innym, aczkolwiek podobnym przedmiotem, są prasy introligatorskie do złoceń, zob. np. D. Subocz, Prasy do złoceń w zbiorach Muzeum Piśmiennictwa i Drukarstwa w Grębocinie. Przyczynek do rozważań o wpływie rozwoju technologii na wyglad XIX-i XX-wiecznych opraw książek, [w:] Sztuka, rzemiosto, przemyst z XIX i XX wieku. Zagadnienia konserwatorskie, pod red. E. Jabłońskiej i J. Czuczko, Toruń 2016, s. 309-316.

133 „Praca” z 25 listopada 1900, r. 4, nr 48, s. 18.

${ }^{134}$ Jego rodzicami byli: Wacław i Maria z d. Urbaniak, zob. APP, AmP - Kartoteka, sygn. 14632, k. 640. 
rą doczekał się trzech potomków ${ }^{135}$. W Poznaniu małżeństwo mieszkało przy następujących ulicach: Wodnej 15, Chwaliszewo 28/29 oraz Krawieckiej $21^{136}$. W połowie czerwca 1931 r. wyprowadzili się do Bydgoszczy, by jednak powrócić do Poznania jeszcze w listopadzie tego samego roku. Po przyjeździe zamieszkali przy ul. Wronieckiej $21 / 22^{137}$.

Stefan prowadził $\mathrm{w}$ drugiej połowie lat $30 . \mathrm{XX} \mathrm{w}$. wytwórnię pieczęci w miejscu zamieszkania, czyli przy ul. Wronieckiej 21/22138. Firma S. Kominowskiego reklamowała się wtedy w prasie za pomocą hasła: „,szybko - tanio - solidnie"139.

KROMCZYŃSKI, Eligiusz (ur. 1 grudnia 1889 r. w Buku - zm. 7 maja 1962 r. w Poznaniu) ${ }^{140}$. Był z zawodu kupcem. Ożeniony z Heleną z d. Drews, ur. 18 maja 1891 r. w Rogoźnie, z którą miał jedną córkę - Oleńkę Barbarę, ur. 25 maja 1921 r. E. Kromczyński mieszkał w Buku do 1905 r., a w 1920 r. wraz z żoną zameldował się przy ul. Dolna Wilda 79 w Poznaniu ${ }^{141}$. We wrześniu 1932 r. zamieszkali pod nowym adresem: Działyńskich 6 m. $5^{142}$.

Kromczyński założył zakład pieczętarski w 1920 r., który najpierw znajdował się przy Alejach Marcinkowskiego $24^{143}$, po-

Il. 4. Anons reklamowy wytwórni stempli Eligiusza Kromczyńskiego z ilustracją stampili datowej. Źródło: „Czasopismo Kas Oszczędności” z 15 stycznia 1926, r. 1, nr 1, s. 18 nlb.

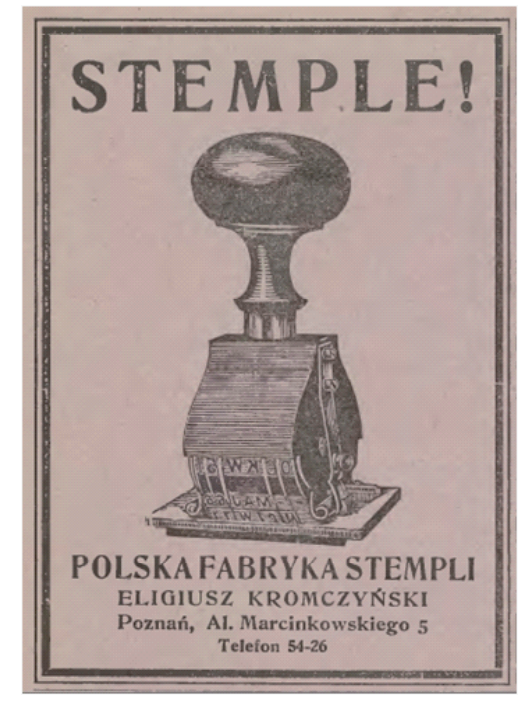

135 Synowie: pierwsze dziecko płci męskiej urodziło się martwe, następnie Eligiusz i Leszek, zob. tamże, k. 641.

136 Tamże, k. 640-641.

137 Tamże, k. 640.

${ }^{138}$ Księga Adresowa dla Handlu - Przemystu - Rzemiosła Stoł. M. Poznania 1936-37, s. 73.

139 Tamże.

140 APP, AmP - Kartoteka, sygn. 14677, k. 84. Jego rodzicami byli: Karl i Anastazja z d. Stoińska, zob. tamże, k. 88. Eligiusz został pochowany na Cmentarzu Górczyńskim w Poznaniu kwatera III, rząd 1, miejsce 34.

141 APP, AmP - Kartoteka, sygn. 14677, k. 85.

142 Tamże.

143 Rocznik dla Handlu i Przemystu na rok 1922: notatnik i niezbędny podręcznik dla pp. kupców, przemysłowców, banków, rolników, hotelistów, etc., etc., oprac. i ułożył M. Kuliński, Poznań 1921, s. 300 nlb. 
tem pod numerem $5^{144}$ i następnie w budynku przy ul. św. Marcin 47 w Poznaniu $^{145}$.

Poza wyrobem pieczęci metalowych i kauczukowych ${ }^{146}$ wykonywał również etykiety wytłaczane ${ }^{147}$, stemple do gil $z^{148}$, sztance do mydła ${ }^{149} \mathrm{i}$ godła mosiężne. Firma Eligiusza zajmowała się także sprzedażą datowników, numeratorów, rowerów (od 1928 r.), części rowerowych i maszyn do szycia ${ }^{150}$.

LOEWENTHAL, Wolff (ur. 7 kwietnia 1847 r. w Poznaniu - zm. 16 marca 1899 r. w Poznaniu) $)^{151}$. Był poznańskim kupcem, wyznania mojżeszowego. Jego żoną była Hulda z d. Rosenthal, ur. w 1855 r., z którą miał pięcioro dzieci $^{152}$. Wolff wraz z rodziną mieszkał wpierw przy ul. Wronieckiej 19 (od lat 70. XIX w. do 1892 r.), a następnie pod numerem 12 (w latach 1892-1899)152.

144 „Czasopismo Kas Oszczędności”: miesięcznik poświęcony sprawom Komunalnych Kas Oszczędności województw zachodnich z 15 stycznia 1926, r. 1, nr 1, s. 18 nlb; Księga Adresowa Miasta Stołecznego Poznania na rok 1930, Dział Branż i Zawodów, s. LVI-LVII; Rocznik Polskiego Przemystu i Handlu 1932, r. 3, poz. 6394.

145 „Rocznik Polskiego Przemysłu i Handlu” 1938, r. 6, poz. 2615; Spis abonentów telefonów m. st. Poznania z uwzględnieniem branż i zawodów 1939, s. 40.

146 Znamy jedynie dwa typariusze sygnowane przez Eligiusza Kromczyńskiego: pieczęć Komisji Dewizowej w Poznaniu (APP, Tłoki, sygn. T IX, 195) i pieczęć bp. Antoniego Laubitza (AGG, sygn. S 302). Zob. ich ilustracje: Zbiór tłoków i stempli pieczętnych..., nr kat. 378; K. Okoniewska, Zbiór tłoków i stempli pieczętnych..., s. 351. Natomiast znany autorom sygnowany znakownik do mięsa z napisem „Wolne od włośni” znajduje się w zbiorach prywatnych.

147 Winiety, etykiety wytłaczane i naklejki tłoczone, stanowią pochodne niemieckich zaklejek (Siegelmarke), które wykonane były w papierze lub gumie, w kształcie okrągłym lub owalnym, zakończone charakterystyczną wielolistną obwolutą. Służyły głównie do zamknięcia korespondencji, zob. np.: Materiaty do polskiego stownika sfragistycznego..., s. 56; Siegelmarke, https://de.wikipedia.org/wiki/Siegelmarke (dostęp: 11.02.2018); S. Bauman, Krakowska rodzina Fischhabów..., s. 222, il. 4 (zob. także przypisy 62-63).

148 Stempel, który służył do napełniania papierosa porcją tytoniu umieszczoną w podłużnej otoczce za pomocą tłoka lub pręta przemieszczającego ją do gilzy papierosowej. Był on wykonany w metalu, w formie pudełka składającego się z dwóch części (po złączeniu tworzył się okrągły otwór), z wyrżniętymi na każdej z nich podłużnymi półokrągłymi rowkami przystosowanymi do standardowej wielkości gilzy.

149 Metalowy stempel (lub patryca), który służył do wytłaczania i sztancowania formy uzyskanej na jego wygrawerowanej (wypukle lub wklęśle) matrycy. Tego typu sztance używano do odciskania np. napisu lub znaku firmowego na mydle (miękki materiał) bądź produkowano je do wybijania guzików (twardy materiał). W literaturze przedmiotu określa się je mianem kształtowników pozytywowych, które - najogólniej mówiąc - służyły do sztancowania i wytłaczania. Szerzej np. M. Gradowski, Technika i technologia w dawnym złotnictwie, Warszawa 1975, s. 38; tegoż, Dawne złotnictwo: technika i terminologia, Warszawa 1984, s. 51.

150 Zob. m.in. Księga Adresowa dla Przemystu, Handlu i Rzemiosła Miasta Poznania 1925, nr ogł. 172; Księga Adresowa Miasta Stołecznego Poznania na rok 1930, Dział Branż i Zawodów, s. LVILVII; „Rocznik Polskiego Przemysłu i Handlu” 1932, r. 3, poz. 6394.

151 APP, AmP - Kartoteka, sygn. 14734, k. 379. Nazwisko Wolffa zapisywano w prasie poznańskiej w dwojaki sposób: Loewenthal lub Löwenthal.

152 Tamże, k. 379-380. 
Na podstawie jednej wzmianki wiemy, że Wolff prowadził przez krótki okres, dokładnie w drugiej połowie lat 90. XIX w., fabrykę pieczęci kauczukowych w budynku przy ul. Wronieckiej $12 \mathrm{w}$ Poznaniu ${ }^{154}$. Poza tym handlował tam także wyrobami gumowymi (Gummiwaren-Händler) ${ }^{155}$.

LORENZ, Józef (Bochum). Właściciel wytwórni stempli156, która znajdowała się w niemieckiej miejscowości Bochum w pierwszej połowie XX w.

$\mathrm{W}$ jedynym odnalezionym ogłoszeniu firmy Józefa Lorenza w prasie poznańskiej oferowano wszelkiego rodzaju i o różnej wielkości stemple. Anonsowano w nim także cenniki firmowe darmo i franko (właśc. franco), co znaczyło tyle, że sprzedający pokrywał koszt wysyłki takowych druków ${ }^{157}$.

NICHT ER, Edw ard (ur. 9 września 1865 r. w Poznaniu - zm. tamże 14 września 1920 r.? ${ }^{158}$. Był z zawodu kupcem. Jego żoną była Berta z d. Schimanski (Szymańska?), ur. 11 lutego 1867 r., z którą miał czworo dzieci'i59.

Na przełomie lat 20. i 30. XX w. Edward założył przedsiębiorstwo, które mieściło się przy ul. Wierzbięcice $30 \mathrm{w}$ Poznaniu, gdzie jedynie handlowano pieczęciami ${ }^{160}$.

PIEKUT, Franciszek (ur. 3 marca 1898 r. w Warszawie) ${ }^{161}$. Grawer, którego rodzicami byli: Leon i Agata z d. Bojanowska. 28 lutego 1924 r. wziął ślub z Zofią z d. Asarów, ur. 25 maja 1903 r. w Bobrujsku ${ }^{162}$. Franciszek przybył do

153 Tamże. Zob. też m.in.: Adress- und Geschäfts-Handbuch der Stadt Posen 1895, s. 86; Adressund Geschäfts-Handbuch der Stadt Posen 1896, s. 108; Adress- und Geschäfts-Handbuch der Stadt Posen 1898, s. 125; Adressbuch der Stadt Posen sowie der Vororte Jersitz, St. Lazarus und Wilda. 1899, s. 133.

154 Adress- und Geschäfts-Handbuch der Stadt Posen 1895, s. 86.

155 Adressbuch der Stadt Posen sowie der Vororte Jersitz, St. Lazarus und Wilda. 1899, s. †15.

156 Firma Józefa Lorenza ogłaszała się w prasie jako polska fabryka stempli, która wyrabia wszelkiego rodzaju „polskie stemple”, zob. „Sokół”. Organ Związku Sokołów Polskich w Państwie Niemieckiem z 1 stycznia 1910, r. 9, nr 1, s. 12. Być może ogłaszającemu chodziło o używane w jego warsztacie czcionki z literami polskiego alfabetu, które wykorzystywano przy produkcji pieczęci gumowych.

157 Tamże.

158 APP, AmP - Kartoteka, sygn. 14854, k. 601. Jego rodzicami byli: Juliusz i Paulina z d. Wunsch, zob. tamże, k. 607.

159 Tamże, k. 603-604.

160 Księga Adresowa Polski (wraz z w. m. Gdańskiem) dla handlu, przemystu, rzemiost i rolnictwa 1928, s. 1423; Księga Adresowa Polski (wraz z w. m. Gdańskiem) dla handlu, przemystu, rzemiost i rolnictwa 1930, s. 1398.

161 APP, AmP - Kartoteka, sygn. 14922, k. 687.

162 Tamże. Bobrujsk - miasto leżące w środkowej części Białorusi, dawniej było miastem powiatowym znajdującym się w guberni mińskiej. Szerzej zob. Stownik geograficzny Królestwa Polskiego i innych krajów stowiańskich, t. 1, s. 265-266. 
Poznania w październiku 1921 r. po odbytej służbie wojskowej. Początkowo mieszkał przy ul. Wodnej 27 (do 1923 r. u Szmidta), potem przy ul. Generała Prądzyńskiego 47 (u Norakowskiej) ${ }^{163}$. Następnie w lutym 1924 r. wyjechał do Warszawy, gdzie przebywał niecałe dwa miesiące. Potem wrócił do Poznania, w którym mieszkał kolejne pięć lat przy następujących ulicach: Górna Wilda 54, Czajcza 12, Dąbrówki 15, Wielka 15 i Aleje Marcinkowskiego $28^{164}$. W maju 1930 r. wyprowadził się do Nakła, a zimą 1932 r. przeprowadził się z Inowrocławia ponownie do Poznania ${ }^{165}$.

Franciszek prowadził na początku lat 30. XX w. zakład grawersko-pieczętarski przy ul. Szewskiej $11 \mathrm{w}$ Poznaniu ${ }^{166}$.

RADKE, Paul (Poznań) ${ }^{167}$. Właściciel drukarni i fabryki stempli, które $\mathrm{w}$ pierwszym dziesięcioleciu XX $\mathrm{w}$. mieściły się w budynku przy Berliner Straße 13 (obecnie ul. Jana Henryka Dąbrowskiego) w Poznaniu ${ }^{168}$.

Należy odnotować, że Radke w ogłoszeniach prasowych odwołuje się do innego poznańskiego wytwórcy pieczęci - Maksymiliana Seydlitza, po którym najpewniej przejął zakład pieczętarski ${ }^{169}$.

W swojej fabryce stempli Radke wytwarzał głównie pieczęcie kauczukowe i metalowe, ale także sprzedawał m.in. artykuły potrzebne do pieczętowania $^{170}$.

ROTHENBURG, Max (ur. 22 września 1872 r. w Berlinie?) ${ }^{171}$. Grawer. W 1895 r. ożenił się z Idą z d. Selzer, ur. 16 grudnia 1875 r. na Łazarzu w Poznaniu. Nowożeńcom, jeszcze na parę miesięcy przed ich ślubem, urodził się syn - Max Gottlieb Ernst ${ }^{172}$. Od kwietnia 1891 r. mieszkali przy ul. Górna Wilda 35 w Poznaniu, następnie parokrotnie zmieniając adres zamieszkania ${ }^{173}$. Ostatecznie rodzina Rothenburgów opuściła Poznań w czerwcu 1920 r., wyprowadzając się do Żytawy (Zittau) $)^{174}$.

163 APP, AmP - Kartoteka, sygn. 14922, k. 687.

164 Tamże, k. 688.

165 Tamże.

${ }^{166}$ Księga Adresowa Polski (wraz z w. m. Gdańskiem) dla handlu, przemystu, rzemiost i rolnictwa 1930, s. 1398.

${ }^{167} \mathrm{~W}$ ogłoszeniach prasowych pojawiają się dwie wersje nazwiska: Radtke i Radke.

168 Adressbuch der Provinzial-Hauptstadt Posen 1910, s. 208; Adressbuch der Provinzial-Haupt und Residenzstadt Posen 1911, s. 212; Adressbuch der Residenzstadt Posen 1912, s. 221.

${ }^{169}$ Np. Adressbuch der Residenzstadt Posen 1912, s. 302*.

170 Tamże.

171 APP, AmP - Kartoteka, sygn. 15002, k. 368.

172 Tamże; APP, AmP - Kartoteka, sygn. 15026, k. 374.

173 Dalsze adresy zamieszkania, zob. APP, AmP - Kartoteka, sygn. 15002, k. 369.

174 Tamże. 
W pierwszym dziesięcioleciu XX w. Max Rothenburg prowadził zakład grawersko-pieczętarski w Poznaniu, wpierw przy Halbdorf Straße 2 (obecnie ul. Półwiejska) ${ }^{175}$, a potem pod numerem 41 (na drugim piętrze) przy tej samej ulicy ${ }^{176}$.

W swojej firmie Rothenburg oferował wyrób wszelkich robót wchodzących w zakres grawerstwa, takich jak np. ryte wypukle i wklęśle monogramy oraz herby na pieczęciach ${ }^{177}$. Poza tym wykonywał m.in. pieczęcie kauczukowe, stemple mennicze i szyldy ${ }^{178}$.

SCHMIDT, Fryderyk (Poznań). Prowadził na początku XX w. zakład pieczętarski i drukarnię $\mathrm{w}$ Poznaniu, których siedziby mieściły się przy ul. Podgórnej $13^{179}$, a potem przy pl. Wolności $7^{180}$. W tym czasie zakład Schmidta ogłaszał się w prasie poznańskiej, w dwóch wersjach językowych w formie polsko- i niemieckojęzycznej ${ }^{181}$.

Fryderyk Schmidt oferował w swojej firmie wszelkie druki oraz stemple metalowe i wykonane w gumie $^{182}$.

SEYDLITZ, Władysław (ur. 27 maja 1857 r. w Poznaniu - zm. 31 grudnia 1906 r. w Poznaniu) ${ }^{183}$. Z wyuczenia introligator. Był żonaty z Marią z d. Kaniewską, ur. 8 września 1864 r. w Kobylinie (ślub wzięli 18 października 1887 r. w Krotoszynie) ${ }^{184}$. Małżeństwo miało pięcioro dzieci, byli to: Mieczysław Franciszek Ksawery ${ }^{185}$, Włodzimierz Roman ${ }^{185}$, Kazimiera Helena, Gottlieba Helena i najmłodszy Bogusław Piotr Paweł ${ }^{186}$.

175 Np. Adressbuch der Provinzial-Hauptstadt Posen 1905, s. 190.

176 Tamże, 1907, s. 199; tamże, 1908, s. 12; Adressbuch der Provinzial-Haupt und Residenzstadt Posen 1911, s. 224; Adressbuch der Residenzstadt Posen 1912, s. 233.

177 Zob. np. Adressbuch der Provinzial-Hauptstadt Posen 1908, s. 12.

178 Zob. np. Adressbuch der Residenzstadt Posen 1912, s. 22.

179 Tamże, s. 243.

180 "Orędownik": najstarsze ludowe pismo narodowe i katolickie w Wielkopolsce z 31 sierpnia 1913, r. 43, nr 200, s. 8 nlb.

${ }^{181}$ Tamże; Adressbuch der Residenzstadt Posen 1912, s. 302*.

182 Tamże.

183 APP, AmP - Kartoteka, sygn. 15028, k. 668. Jego matką była Emilia Seydlitz z d. Goltz (1817-1885), która urodziła jeszcze czwórkę dzieci - trzy córki (Matyldę, Martę i Judytę) oraz syna Maksymiliana, zob. APP, AmP - Kartoteka, sygn. 15019, k. 155-156. W prasie poznańskiej znalazł się także nekrolog Władysława Seydlitza, zob. „Kurier Poznański” z 3 stycznia 1907, r. 2, nr 2, s. 4. Odnotowaliśmy w prasie poznańskiej, że zapisywano dwojako nazwisko Władysława i Maksymiliana jako: Seydlitz i Seidlitz.

${ }^{184}$ APP, AmP - Kartoteka, sygn. 15028, k. 668.

185 Ur. 18 lipca 1888 r. w Poznaniu - zm. w 1954 r. Jego żoną była Anna Teofilia z d. Lamparska, ur. 27 kwietnia 1895 r. Prawnik z tytułem doktora prawa, bankowiec, urzędnik samorządowy w II Rzeczypospolitej. W Poznaniu był początkowo bankowcem, potem został dyrektorem banku. W 1921 r. kandydował do Rady Miasta Poznania z ramienia Związku 
Władysław był właścicielem drukarni i zakładu pieczętarskiego, które założył w 1886 r. w Poznaniu. Przedsiębiorstwo Seydlitza mieściło się w wielu miejscach na przestrzeni kilkudziesięciu lat, były to następujące adresy: ul. św. Marcin 76 (w 1888 r.) ${ }^{188}$, Waisenstraße 9 (w latach 1889-1893; obecnie ul. Sieroca) $)^{189}$, Ziegelstraße 14 (w latach 1894-1895; obecnie ul. Grudzieniec) ${ }^{190}$, Neustraße 4 (w latach 1895-1896; obecnie ul. Paderewskiego) ${ }^{191}$, ponownie Sieroca 9 (w latach 1897-1898) ${ }^{192}$, Wrocławska 30 (w latach 1899-1903) ${ }^{193}$ oraz ostatni odnotowany adres firmy - pl. Wolności 18 (około lat 1903-1905?) ${ }^{194}$. Po krótkim okresie samodzielnej działalności Władysław prawdopodobnie zaczął prowadzić jedynie drukarnię i introligatornię, a jego młodszy brat Maksymilian przejął zakład pieczętarski. Ponadto Władysław Seydlitz był współzałożycielem poznańskiego oddziału Towarzystwa Gimnastycznego „Sokół" i pierwszym jego prezesem oraz przewodniczącym zarządu ${ }^{195}$.

Bankowców, przez co działał w latach 1922-1925 jako radny. Dalsza jego kariera zawodowa związana jest z pełnionymi urzędami wicewojewody (pomorski, kielecki i stanisławowski) i wojewody (pomorski). Szerzej zob. APP, AmP - Kartoteka, sygn. 15019, k. 149; K. Przybyszewski, Seydlitz Mieczystaw Franciszek Ksawery (1888-1954), dr praw, wicewojewoda pomorski i stanistawowski, [w:] Toruński stownik biograficzny, t. 4, pod red. K. Mikulskiego, s. 218-220; tegoż, Od zaborów do emigracji: Mieczystaw Franciszek Ksawery Seydlitz (1888-1954), doktor praw, wicewojewoda pomorski i stanisławowski, „Nowości” z 18 sierpnia 2003, r. 36, nr 191, s. 21.

186 Ur. 11 stycznia 1890 r. w Poznaniu - zm. w czasie zsyłki w głąb ZSRR w 1940 r. Od 1937 r. jego żoną była Felicja Kaczorowska, z którą nie miał dzieci. Włodzimierz był zawodu prawnikiem, pracował jako bankowiec i działał w ruchu spółdzielczym. W 1929 r. został odznaczony Krzyżem Komandorskim Orderu Polonia Restituta. Szerzej m.in.: A. Dzięczkowski, Seydlitz Włodzimierz Roman (1890-1940), [w:] PSB, t. 36, s. 370-373; tegoż, Seydlitz Włodzimierz Roman (1890-1940), [w:] WSB, s. 657-658.

187 APP, AmP - Kartoteka, sygn. 15028, k. 668-669. Najmłodszy z braci Seydlitzów Bogusław (1899-1971) był również bardzo dobrym i wziętym poznańskim prawnikiem.

188 Adress- und Geschäfts-Handbuch der Stadt Posen 1888, s. 19.

189 Tamże, 1889, s. 113; tamże, 1890, s. 121; tamże, 1893, s. 114.

190 Adress- und Geschäfts-Handbuch der Stadt Posen nebst der vororte Bartholdshof, Berdychowo, Jersitz, St. Lazarus, Pietrowo und Wilda 1894, s. 123.

191 Tamże, 1895, s. 133; „Praca”: tygodnik polityczny i literacki, ilustrowany z 7 listopada 1896, r. 1, nr 7, s. 3.

192 Adress- und Geschäfts-Handbuch der Stadt Posen nebst der vororte Bartholdshof, Berdychowo, Jersitz, St. Lazarus, Pietrowo und Wilda 1896, s. 170; Adressbuch der Stadt Posen sowie der Vororte Bartholdshof, Jersitz, St. Lazarus und Wilda 1898, s. 197.

${ }_{193}$ Adressbuch der Stadt Posen sowie der Vororte Bartholdshof, Jersitz, St. Lazarus und Wilda 1899, s. 210; Adressbuch der Provinzial-Hauptstadt Posen für das Jahr 1902, s. 223.

194 Adressbuch der Provinzial-Hauptstadt Posen für das Jahr 1903, s. 213; Adressbuch der Provinzial-Hauptstadt Posen 1905, s. 208; „Komar”. Miesięcznik Ilustrowany Satyryczno-Humorystyczny z sierpnia 1904, r. 4, nr 41, s. 650; „Komar”. Miesięcznik Ilustrowany Satyryczno-Humorystyczny z lutego 1905, r. 5, nr 47, s. 783.

195 Sprawozdanie Towarzystwa Gimnastycznego w Poznaniu, „Goniec Wielkopolski” z 25 grudnia 1886, r. 10, nr 295, s. 3. Więcej np. T. Kryg, Zarys dziejów dwudziestopięciolecia "Sokota" poznańskiego, [w:] Srebrna Księga Sokoła Poznańskiego, Poznań 1911, s. 3-4; W. Weselik, Pięćdziesiąt lat „Sokoła" Poznańskiego, [w:] Złota Księga Sokoła Poznańskiego, Poznań 1936, s. 20-21. 
Zakład pieczętarski Seydlitzów wytwarzał przede wszystkim pieczęcie kauczukowe i metalowe, ale sprzedawano w nim również medaliony, wszelkie stemple do biur, znakowniki, datowniki, numeratory oraz akcesoria do sporządzania pieczęci ${ }^{196}$. Firma oferowała także usługi drukarskie (np. wykonywała karty wizytowe) i wszelkie roboty introligatorskie ${ }^{197}$.

W latach 1905-1910 odnotowujemy anonse Paula Radkego, w których ogłaszający mieni się kontynuatorem działalności zakładu Seydlitzów ${ }^{198}$. Zdarzało się, że pracownie wraz z ich wyposażeniem były przejmowane przez innych pieczętarzy. Być może więc przykładem takiej praktyki był właśnie warsztat prowadzony początkowo przez Seydlitzów, a potem Paula Radkego.

SEYDLITZ, Maksymilian (ur. 5 września 1859 r. w Poznaniu) ${ }^{199}$. Młodszy brat Władysława Seydlitza, który prowadził jeden z dwóch rodzinnych interesów - zakład pieczętarski, samodzielnie nim kierując prawdopodobnie od 1889 r., ponieważ od wtedy pojawiają się pierwsze ogłoszenia jedynie z jego imieniem $^{200}$.

SKORUPSKI, Bernard (Poznań). Właściciel zakładu grawersko-pieczętarskiego przy ul. św. Marcin $25 \mathrm{w}$ Poznaniu ${ }^{201}$.

$\mathrm{W}$ warsztacie B. Skorupski wykonywał przede wszystkim roboty grawerskie, ale także handlował, m.in. datownikami kauczukowymi, numeratorami metalowymi i paginatorami ${ }^{202}$.

STEINBERG, Karol (ur. 26 października 1884 r. w Warszawie - zm. po 1931 r. w Poznaniu[?] ${ }^{203}$. Z zawodu mechanik. Był żonaty z Felicją z d. Lertus $^{204}$.

Założyciel zakładu grawerskiego, który w latach 30. XX w. mieścił się przy ul. Półwiejskiej 9b w Poznaniu. Ogłaszający się zaznaczył w jednym ze swoich anonsów, że jego firma jest „chrześcijańską" ${ }^{205}$. Karol przyjmował

196 „Praca”: tygodnik polityczny i literacki, ilustrowany z 7 listopada 1896, r. 1, nr 7, s. 3; Kalendarz Przemystowy na Rok Pański 1889, s. 180.

197 Zob. np. Adress- und Geschäfts-Handbuch der Stadt Posen 1888, s. 19.

198 Zob. przypis 169.

199 APP, AmP - Kartoteka, sygn. 15019, k. 156. Zob. także przypis 182.

${ }^{200}$ Kalendarz Przemystowy na Rok Pański 1889, s. 180.

201 Spis abonentów sieci telefonicznej państwowej w Krakowie na rok 1934, nr poz. 504 (pieczęcie stemple: Poznań); Księga Adresowa dla Handlu - Przemystu - Rzemiosta Stot. M. Poznania 1936-37, s. 65 (rytownictwo).

202 Tamże.

${ }^{203}$ APP, AmP - Kartoteka, sygn. 15073, k. 440.

${ }^{204}$ Tamże.

${ }^{205}$ Ksiega Adresowa dla Handlu - Przemystu - Rzemiosta Stot. M. Poznania 1936-37, s. 51 (mosiężnictwo). 
$\mathrm{w}$ warsztacie zlecenia m.in. na: pieczęcie metalowe i kauczukowe, szyldy mosiężne i emaliowane, medale, żetony oraz odznaki ${ }^{206}$.

SZMYT, Ludwik (Poznań). Właściciel fabryki stempli, która znajdowała się $\mathrm{w}$ drugiej połowie lat 20. XX w. przy ul. Wielkiej $1 \mathrm{w}$ Poznaniu ${ }^{207}$.

"WĄSIK \& GODLEWSKI" (Poznań). Spółkę założyli dwaj rzemieślnicy: Stefan Wąsik ${ }^{208}$ i Walerian Godlewski ${ }^{209}$. Główną działalnością firmy było rytownictwo. W latach 30. XX w. siedziba firmy znajdowała się przy Alejach Marcinkowskiego 7 w Poznaniu ${ }^{210}$.

Zakład firmy „Wąsik i Godlewski” wykonywał głównie medale, odznaki, żetony i pieczęcie ${ }^{211}$.

Nie ulega wątpliwości, że grawerzy pieczęci, w latach zasygnalizowanych $\mathrm{w}$ tytule artykułu, działali przede wszystkim w większych miastach. Wymienieni kupcy i rzemieślnicy charakteryzowali się jeszcze dużą mobilnością, albowiem bardzo często zmieniali miejsce zamieszkania oraz lokalizacje zakładu lub siedziby firmy w granicach Poznania ${ }^{212}$. Przy tym usytuowanie ich wytwórni koncentrowało się w centrum miasta. Możemy także zaobserwować, że zakłady poznańskich wytwórców pieczęci posiadały bogatą, ale jednocześnie zbliżoną do siebie ofertę. Przedsiębiorstwa, takie jak np. składy papieru i galanterii, parały się sprzedażą gotowych typariuszy i maszyn pieczętujących oraz wielu innych akcesoriów związanych z pieczętowaniem (np. tusze do pieczęci lub poduszki z farbą do maczania). Ta rozpiętość usług może świadczyć m.in. o tym, że sprzedaż samych pieczęci była niewystarcza-

206 Tamże.

207 Książka Adresowa Miasta Stołecznego Poznania 1926, cz. III, Spis branż i zawodów, s. 376*.

208 Grawer, który pojawia się w spisach grawerów i rytowników pieczęci w drugiej połowie lat 20. XX w., zob. Księga Adresowa Polski (wraz z w. m. Gdańskiem) dla handlu, przemystu, rzemiost i rolnictwa 1926-27, s. 719; Księga Adresowa Polski (wraz z w. m. Gdańskiem) dla handlu, przemystu, rzemiost i rolnictwa 1928, s. 1423.

${ }^{209}$ Ur. 2 grudnia 1892 r. w Grodzicach. Jego rodzicami byli: Antoni i Marcela z d. Wróblewska. Był z zawodu rytownikiem, który w 1922 r. przybył z Warszawy do Poznania, zob. APP, AmP - Kartoteka, sygn. 14439, k. 422.

${ }^{210}$ Księga Adresowa Miasta Stołecznego Poznania na rok 1933, Dział III, s. 22; Księga Adresowa dla Handlu - Przemystu - Rzemiosta Stot. M. Poznania 1936-37, s. 65.

211 Tamże.

212 Szerzej o mobilności mieszkańców Poznania w pierwszej połowie XIX w. zob. K. Makowski, Rodzina poznańska w I połowie XIX wieku, Poznań 1992, s. 64-68 (przedruk: KMP 2017, nr 4, s. 62-66). 
jąca w ramach działalności takich sklepów. Wskazuje to również na większą mechanizację i specjalizację urządzeń pieczętujących (numeratory, datowni$\mathrm{ki}$, prezentatory itd.), co wiąże się z rozszerzeniem biurokracji, a co za tym idzie - $\mathrm{z}$ rozwojem form kancelaryjnych ${ }^{213}$. Ponadto należy zwrócić uwagę na to, że spora liczba wytwórców pieczęci była z zawodu drukarzami bądź introligatorami lub ślusarzami, co z kolei pozwalało na łączenie tych działalności w ramach firmy. Często spośród grawerów i rytowników wyłaniali się pieczętarze, aczkolwiek bazujemy na kartach meldunkowych, gdzie wpisywano jedynie zawód (wyuczony?), więc często nie jesteśmy w stanie powiedzieć więcej na temat drogi rzemieślniczej poszczególnego wytwórcy. Brak - jak dotąd - szerszego zainteresowania badaczy nad wytwórcami pieczęci spowodował, że nie dysponujemy opracowaniem, które w wystarczający sposób formułuje wnioski na temat np. opłacalności tego zawodu ${ }^{214} \mathrm{czy}$ realiów życia i prac takiego pieczętarza ${ }^{215}$. Na podstawie stanu badań udało się wyodrębnić tylko kilka pełniejszych biogramów wytwórców (przede wszystkim Belowa, Dmochowskiego i Kapeli), które zostały zasygnalizowane w powyższym artykule. Niemniej jednak należy podkreślić, że temat ten jest perspektywiczny i będzie wymagał dalszych badań.

\title{
Bibliografia
}

\author{
Źródła archiwalne \\ Archiwum Archidiecezjalne w Gnieźnie \\ Tłoki i stemple pieczętne, sygn. S 36, 37, 53, 58, 72, 202, 274, 302, 308.
}

${ }^{213}$ Np. S. Nawrocki, Rozwój form kancelaryjnych na ziemiach polskich od średniowiecza do końca XX wieku, Poznań 1998, s. 93-187.

${ }^{214}$ Udało się dotąd odnaleźć jedynie jeden rachunek z omawianego czasu, w którym zawarto informację o cenie usługi. Jest to rachunek wystawiony 16 lutego 1903 r. w Poznaniu przez firmę M. Seydlitza, gdzie za wykonanie (lub sprzedaż?) trzech numeratorów i jednej poduszki z farbą do pieczęci podaje się cenę "7 Mark, 25 Pfennig", zob. MHMP, sygn. D 5101. Problematykę cen wyrobów pieczętarskich będzie można szerzej przebadać, kiedy odnajdziemy więcej katalogów i cenników firmowych.

${ }^{215}$ Podstawową działalnością zakładów grawersko-pieczętarskich w drugiej połowie XIX i pierwszej połowie XX w. był wyrób drobnych przedmiotów metalowych, takich jak np.: odznaki, medale, medaliki, plakiety, żetony itd. $W$ ogłoszeniach prasowych prezentowanych wyżej wytwórców często pojawia się zwrot: „wykonuję wszelkie roboty wchodzące w zakres rytownictwa [lub grawerstwa]". Ten komunikat oznajmiał wykonywanie podstawowych prac grawerskich, do których należało wycinanie, obrabianie i rytowanie drobnych przedmiotów z metalu. Dodatkowo do poprawienia dokładności i usprawnienia wykonywania pieczęci od początku XX w. przyczynił się rozwój maszynowego rytownictwa. Szersze omówienie wytwórczości pieczęci znajdzie się $\mathrm{w}$ anonsowanych we wstępie materiałach do słownika wytwórców pieczęci XIX i XX w. 
Archiwum Państwowe w Poznaniu

Akta miasta Poznania - Kartoteka ewidencji ludności 1870-1931, sygn. 14270, k. 551-552; 14271 , k. 126-128; 14279, k. 74-75; 14304, k. 222-223; 14328, k. 219; 14369, k. 504-505; 14380 , k. $827-828 ; 14439$, k. $422 ; 14505$, k. $1021 ; 14526$, k. $171 ; 14547$, k. 25-26; 14580, k. 349-350; 14582, k. 316-317; 14621, k. 440-441; 14677, k. 84-85; 14854, k. 601, 603-604, $607 ; 14632$, k. 640-641; 14734, k. 379-380; 14911, k. 149-151; 14922, k. 687-688; 15002, k. 368-369; 15019, k. 149, 155-156; 15026, k. 374; 15028, k. 668-669; 15049, k. 778-781; 15073, k. 440; 15074, k. 1015.

Centrala Przesiedleńcza w Poznaniu 1939-1940, sygn. 10.

Tłoki, sygn. T IV , 2, 16, 27, 35, 50; T V, 25, 40; T IX, 99, 195, 197-202, 227-228, 238, 249, 251, 253-254; T X, 23, 34, 151, 172, 184, 194; T XI, 5.

Urząd Powierniczy w Poznaniu, sygn. 13675, 14004.

Urząd Wojewódzki Poznański, sygn. 3158.

KZ-Gedenkstätte Mauthausen - Mauthausen Memorial, sygn. AMM/Y/36a, 46a, 50.

Muzeum Historii Miasta Poznania - Oddział Muzeum Narodowego w Poznaniu

Druki ulotne, sygn. MNP D 2258, 3140/3, 3173/1, 3472, 3965, 5101, 11.354.

Muzeum Mazowieckie w Płocku

Tłoki pieczętne, sygn. MMP/S/8291.

Muzeum Narodowe Rolnictwa i Przemysłu Rolno-Spożywczego w Szreniawie

Zbiory historyczne, sygn. MNR H-481, 1153-1154, 1442.

Muzeum Regionalne im. Dzieci Wrzesińskich we Wrześni

Zbiory sfragistyczne, sygn. MRW 128, 2098, 2224-2225, 2227.

Muzeum Regionalne w Stęszewie

Zbiory sfragistyczne, sygn. MRSt 72-73, 583, 1554.

Zbiory prywatne autorów

pieczęć prywatna z inicjałami „N. S. G.”.

\section{Źródła drukowane}

Adressbuch der Provinzial-Hauptstadt Posen sowie der Vororte Jersitz, St. Lazarus und Wilda, Posen 1900.

Adressbuch der Provinzial-Hauptstadt Posen für das Jahr..., Posen 1901-1904.

Adressbuch der Provinzial-Hauptstadt Posen, Posen 1905-1908, 1910.

Adressbuch der Provinzial-Haupt und Residenzstadt Posen, Posen 1911.

Adressbuch der Residenzstadt Posen, Posen 1912-1914.

Adressbuch der Residenzstadt Posen, Posen 1916-1917.

Adressbuch der Stadt Posen, Posen 1886-1889.

Adressbuch der Stadt Posen sowie der Vororte Bartholdshof, Jersitz, St. Lazarus und Wilda, Posen 1898.

Adressbuch der Stadt Posen sowie der Vororte Jersitz, St. Lazarus und Wilda, Posen 1899.

Adressbuch für die Stadt Posen, Posen 1872 (druk 1871), 1876 (druk 1875).

Adress- und Geschäfts-Handbuch der Stadt Posen, Posen 1879, 1882, 1885, 1890-1893.

Adress- und Geschäfts-Handbuch der Stadt Posen nebst der vororte Bartholdshof, Berdychowo, Jersitz, St. Lazarus, Pietrowo und Wilda, Posen 1894-1896.

Deutsches Reichs-Adressbuch für Industrie, Gewerbe, Handel, Bd. 2, Berlin 1920.

Jana Łaskiego, arcybiskupa gnieźnieńskiego, prymasa, legata urodzonego Liber beneficiorum archidyecezyi gnieźnieńskiej z poręki Towarzystwa Przyjaciót Nauk Poznańskiego podług kodeksów rękopiśmiennych archiwum gnieźnieńskiego i kaliskiego. T. 2, Obejmujący Archidyakonaty: Kaliski, Wieluński, Łowicki i Łęczycki, oprac. J. Łukomski, Gniezno 1881.

Kalendarz Przemystowy wydany staraniem Towarzystwa Młodych Przemystowców w Poznaniu na Rok Pański 1889, Poznań 1889. 
Kalendarz Przemystowy wydany staraniem Towarzystwa Młodych Przemystowców w Poznaniu na Rok Pański 1891, Poznań 1891.

Książka adresowa handlu i przemystu Polskiego w obrębie niemieckiego państwa obejmująca adresy fabrykantów, kupców i samodzielnych rzemieślników, r. 1: 1896-1897, Berlin 1896.

Książka Adresowa Miasta Bydgoszczy na rok 1928, oprac. i wyd. W. Weber, Bydgoszcz 1929.

Książka Adresowa Miasta Stołecznego Poznania, Poznań 1926.

Księga Adresowa dla Handlu - Przemystu - Rzemiosta Stot. M. Poznania 1936-37, Poznań 1936-1937.

Ksiega Adresowa Miasta Stołecznego Poznania na rok 1930, Poznań 1929.

Ksiega Adresowa Miasta Stołecznego Poznania na rok 1933, Poznań 1932.

Ksiega Adresowa Polski: przemystu, handlu, finansów, szkolnictwa, wolnych zawodów i organizacji spotecznych, wyd. czwarte, Warszawa 1937.

Ksiegga Adresowa Polski (wraz z w. m. Gdańskiem) dla handlu, przemystu, rzemiost i rolnictwa 1926/27, Warszawa 1926.

Ksiegga Adresowa Polski (wraz z w. m. Gdańskiem) dla handlu, przemystu, rzemiost i rolnictwa, Warszawa 1928.

Księga Adresowa Polski (wraz z w. m. Gdańskiem) dla handlu, przemystu, rzemiost i rolnictwa, Warszawa 1930.

Pamiątkowy Kalendarz Przemystowy wydany staraniem Towarzystwa Młodych Przemystowców w Poznaniu w dziesiąta rocznice jego istnienia na rok przestępny 1884, Poznań 1884.

Pamiętnik Wystawy Przemystowej w Poznaniu z roku 1908, Poznań 1909.

Posener Wohnungs-Anzeiger auf das Jahr..., Posen 1855, 1862, 1865, 1868.

Rocznik Polskiego Przemystu i Handlu, r. 3: 1932; r. 4: 1934; r. 5: 1936; r. 6: 1938.

Rocznik dla Handlu i Przemystu na rok 1922: notatnik i niezbędny podręcznik dla pp. kupców, przemysłowców, banków, rolników, hotelistów, etc., etc., oprac. i ułożył M. Kuliński, Poznań 1921.

Stownik geograficzny Królestwa Polskiego i innych krajów stowiańskich, wyd. pod red. F. Sulimierskiego, B. Chlebowskiego, W. Walewskiego, Warszawa 1880, t. 1.

Spis Abonentów Sieci Telefonicznej Okręgu Dyrekcji Poczt i Telegrafów w Bydgoszczy: w marcu 1926 r., Bydgoszcz 1926.

Spis abonentów telefonów m. st. Poznania z uwzględnieniem branż i zawodów 1939, Poznań 1939.

Sprawozdanie z czynności Katolickiego Towarzystwa Rzemieślników Polskich pod wezwaniem św. Józefa w Poznaniu z roku 1905, Poznań 1906.

\section{Prasa}

„Czasopismo Kas Oszczędności” 1926, r. 1, nr 1, s. 18 nlb.

„Dziennik Poznański” 1874, r. 16, nr 167, s. 4; 1892, r. 34, nr 92, s. 5; 1895, r. 37, nr 165, s. 6; 1895, r. 37, nr 166, s. 4.

„Goniec Wielkopolski” 1880, r. 4, nr 285, s. 2; 1886, r. 10, nr 295, s. 3; 1895, r. 19, nr 165, s. 3-4; 1895, r. 19, nr 167 , s. 2.

„Komar" 1904, r. 4, nr 41, s. 650; 1905, r. 5, nr 47, s. 783.

„Kurier Poznański" 1907, r. 2, nr 2, s. 4; 1908, r. 3, nr 235, s. 8; 1930, r. 25, nr 474, s. 6; 1930, r. 25, nr 476, s. 9.

„Łowiec Wielkopolski” 1907, r. 1, nr 11, s. 178 nlb.

"Nowy Kurjer" 1930, r. 41, nr 102, nr ogłoszenia 2138.

"Orędownik" 1913, r. 43, nr 200, s. 8.

„Posener Tageblatt" 1899, Jg. 38, nr 121, s. 12; 1899, Jg. 38, nr 201, s. 12; 1908, Jg. 47, nr 479, s. 6.

„Praca” 1896, r. 1, nr 7, s. 3; 1900, r. 4, nr 48, s. 18.

„Przemysłowiec” 1908, r. 5, nr 29, s. 230; 1911, r. 8, nr 43, s. 8.

"Sokół" 1910, r. 9, nr 1, s. 12.

"Wielkopolanin" 1883, r. 1, nr 20, s. 4; 1883, r. 1, nr 64, s. 4; 1884, r. 2, nr 15, s. 4; 1884, r. 2, nr 100, s. $4 ; 1897$, r. 15, nr 89 , s. 7.

„Ziemianin" 1912, r. 63, nr 17, s. 108 nlb. 


\section{Wydawnictwa elektroniczne}

Bauman S., Chrząszcz P., Bolestaw Kapela (1891-1942), http://www.gedenkstaetten.at/raumdernamen/cms/index.php?id=4\&p=8311\&L=1 (dostęp: 6.08.2018).

Okoniewska K., Najstynniejsi poznańscy wytwórcy pieczęci, http://ehistoria.edu.pl/main/articles/show/article:Najslynniejsi-poznanscy-wytworcy-pieczeci-120/ (dostęp: 14.09.2018).

Siegelmarke, https://de.wikipedia.org/wiki/Siegelmarke (dostęp: 11.02.2018).

Wyższa Szkota Graficzna w Poznaniu, Poznań ok. 1930, http://www.wbc.poznan.pl/dlibra/docmetadata?id=2196\&from=publication (dostęp: 1.06.2019).

\section{Opracowania}

Baniecki A., Bednarek D., Żygadło D., Forysiak-Wójciński R., Gut P., Leśniewska J., Hlebionek M., Materiaty do polskiego stownika sfragistycznego, „Archiwista Polski” 2010, t. 3, s. 4356.

Bauman S., Krakowska firma rytowniczo-pieczętarska Aleksandra Fischhaba, Poznań 2018 (praca magisterska niepublikowana, napisana pod kierunkiem dr. hab. Pawła Stróżyka, prof. UAM, dostępna w Archiwum Prac Dyplomowych Wydziału Historycznego UAM w Poznaniu).

Bauman S., Krakowska rodzina Fischhabów i jej firma rytowniczo-pieczętarska w latach 1900/19041950, [w:] Cracoviensis civitas - singulare totius Poloniae decus. Materiały z I oraz II Ogólnopolskiej Studencko-Doktoranckiej Konferencji Naukowej "Kraków na przestrzeni dziejów”, red. nacz. M. Chruściak, red. nauk. Z. Piech, M. Stinia, Kraków 2018, s. 207-232.

Bauman S., Chrząszcz P., Warszawski zakład pieczętarski Zygmunta Weinkrantza, [w:] Żydzi polscy na przestrzeni wieków. Materiały z III Krakowskiej Konferencji Judaistycznej, red. S. Gąsiorowski, Kraków 2018, s. 11-29.

Bobrow R., Warszawscy złotnicy, jubilerzy, grawerzy i kupcy wyrobów kruszcowych w XIX wieku, Warszawa 2018.

Bobrow R., Złotnicy i jubilerzy prowincji Królestwa Polskiego, Warszawa 2017.

Cenniejsze dary i nabytki Muzeum Narodowego w Poznaniu (1993-1994), „Studia Muzealne. Muzeum Narodowe w Poznaniu" 1994, z. 28, s. 107-148.

Dolczewski Z., "Salonik damski" $i$ "Pokój męski w tyrolskim gotyku”. Wyposażenie domów z poznańskich wytwórni w XIX w., „Kronika Miasta Poznania” 1994, nr 1-2, s. 143-183.

Dzięczkowski A., Seydlitz Wtodzimierz Roman (1890-1940), [w:] Polski stownik biograficzny, t. 36, s. 370-373.

Dzięczkowski A., Seydlitz Wtodzimierz Roman (1890-1940), [w:] Wielkopolski stownik biograficzny, Warszawa-Poznań 1981, s. 657-658.

Gibasiewicz S., Biatas Jan (1866-1905), [w:] Wielkopolski stownik biograficzny, Warszawa-Poznań 1981, s. 51-52.

Gradowski M., Dawne złotnictwo: technika i terminologia, Warszawa 1984.

Gradowski M., Technika i technologia w dawnym złotnictwie, Warszawa 1975.

Hinc A., "Na waszym grobie, waleczni kosarze...": motyw kosyniera w poznańskiej Wiośnie Ludów, „Kronika Miasta Poznania” 2008, nr 1, s. 306-314.

Jachowski J., Bolestaw Kapela, [w:] Polski stownik biograficzny, t. 11, s. 626.

Jachowski J., Kapela Ludwik i Bolesław, [w:] Stownik pracowników ksiażki polskiej, Warszawa-Łódź 1972, s. 395-396.

Jachowski J., Ludwik Kapela, [w:] Polski stownik biograficzny, t. 11, s. 626-627.

Karolczak W., Biżuteria i zegarki z polska symbolika patriotyczna w sklepach jubilerskich w Poznaniu pod koniec XIX wieku, „Kronika Miasta Poznania” 2000, nr 1, s. 162-180.

Korduba P., Sołacz: domy i ludzie, Poznań 2012.

Kozłowski J., Administracja Wielkopolski pod pruskim zaborem 1793-1918, Poznań 2000. 
Kryg T., Zarys dziejów dwudziestopięciolecia „Sokoła” poznańskiego, [w:] Srebrna Księga Sokoła Poznańskiego, Poznań 1911, s. 3-34.

ŁuczakJ.,Arcydzieła sztukigrawerskiej. Kolekcja odznakwojskowych z pracowni Jarostawa Jakubowskiego z Poznania ofiarowana do zbiorów Wielkopolskiego Muzeum Wojskowego, Poznań 2016.

Majkowski E., Fryderyk Wilhelm Below: pieczętarz i medaljer poznański, patriota polski (1822-1895), „Kronika Miasta Poznania” 1936, r. 14, nr 3, s. 263-349.

Makowski A.K., Mieszkańcy Poznania w I połowie XIX wieku, „Kronika Miasta Poznania” 2017, nr 4, s. 51-66.

Makowski K., Rodzina poznańska w I połowie XIX wieku, Poznań 1992.

Małecki A., Kandziora Karol Marcin (1882-1944), [w:] Wielkopolski stownik biograficzny, WarszawaPoznań 1981, s. 313.

Męczyńska K., Poznańskie rody i rodziny - Szulcowie: Muzeum Narodowe w Poznaniu: wystawa 2 kwietnia - 22 maja 2006 w Muzeum Historii Miasta Poznania - Ratusz, Poznań 2006.

Mniszek H., Verte. Powieść: dwie części w jednym tomie, Poznań 1923.

Mrugalska-Banaszak M., Wilda w czterech odstonach 1235-1945, Poznań 2018.

Mulczyński J., Rodzina Ludwika i Bolestawa Kapelów na Sołaczu, „Kronika Miasta Poznania” 1999, t. $67, \mathrm{nr} 3, \mathrm{s.} 232-248$.

Murawska A., Seweryn Mielżyński. Szkic do portretu dobrze zastużonego, [w:] Seweryn Mielżyński 1804-1872, oprac. K. Gieszczyńska-Nowacka, T.I. Grabski, M.P. Michałowski, A. Murawska, E. Siejkowska-Askutja, Poznań 2018, s. 9-51.

Nawrocki S., Rozwój form kancelaryjnych na ziemiach polskich od średniowiecza do końca XX wieku, Poznań 1998.

Okoniewska K., Zbiór tłoków i stempli pieczętnych w Archiwum Archidiecezjalnym w Gnieźnie. Komunikat z V Sesji Mecenatu Skarbów Stowa (12.06.2017 r.), „Studia Gnesnensia” 2017, t. 31, s. 347-356.

Piotrowski A., 50 dni rządów Rady Robotników i Żotnierzy w Poznaniu, Poznań 1919.

Pniewski W., Akademja Poznańska. Szkic historyczny, Poznań 1919.

Polityczna dziatalność rzemiosła wielkopolskiego w okresie zaborów (1793-1918), oprac. T. Filipiak, Z. Grot, F. Paprocki, L. Trzeciakowski, T. Wiesiołowski, Poznań 1963.

Popiołek E., Ttoki pieczętne w zbiorach płockich, Płock 1983.

Przybyszewski K., Od zaborów do emigracji: Mieczystaw Franciszek Ksawery Seydlitz (1888-1954), doktor praw, wicewojewoda pomorski i stanistawowski, „Nowości” z 18 sierpnia 2003 r., r. 36, nr 191, s. 21.

Przybyszewski K., Seydlitz Mieczystaw Franciszek Ksawery (1888-1954), dr praw, wicewojewoda pomorski i stanistawowski, [w:] Toruński stownik biograficzny, t. 4, pod red. K. Mikulskiego, s. $218-220$.

Rościszewski M., Pisarz i doradca: Podręcznik praktyczny dla osób nie obytych z piórem zawierajacy rozmaite sposoby pisania listów, prowadzenia korespondencji w sprawach urzędowych, prywatnych i kupieckich, Lwów-Poznań 1921.

Rudawski B., Grabież mienia w Kraju Warty 1939-1945. Działalność Urzędu Powierniczego w Poznaniu, Poznań 2018.

Rzepecki K., Pułk Czwarty 1830-1831. Szkic historyczny wedtug relacji ustnej i pamiętnikarskich notatek Kajetana Władystawa Rzepeckiego, Poznań 1923.

Sokolnicka D., Szulc Walerian (1849-1901), [w:] Wielkopolski stownik biograficzny, WarszawaPoznań 1981, s. 744-745.

Streubel C., Grawerstwo, Warszawa 1959.

Strzałkowski J., Słownik medalierów polskich i z Polską związanych 1508-1965. (Materiały), Warszawa 1982.

Subocz D., Prasy do złoceń w zbiorach Muzeum Piśmiennictwa i Drukarstwa w Grębocinie. Przyczynek do rozważań o wptywie rozwoju technologii na wyglad XIX- i XX-wiecznych opraw ksiażek, 
[w:] Sztuka, rzemiosło, przemyst z XIX i XX wieku. Zagadnienia konserwatorskie, pod red. E. Jabłońskiej i J. Czuczko, Toruń 2016, s. 309-316.

Szulc E., Materiaty do biografii medalierów, grawerów stempli, pracowników mennicy i numizmatyków w świetle akt parafii ewangelickich w Warszawie, „Wiadomości Numizmatyczne” 1982, r. XXVI, z. 1-2, s. 33-47.

Weselik W., Pięćdziesiąt lat "Sokoła” poznańskiego, [w:] Złota Księga Sokoła Poznańskiego, Poznań 1936, s. 19-52.

Zbiór tłoków i stempli pieczętnych w zasobie Archiwum Państwowego w Poznaniu, oprac. M. Górny, M. Hlebionek, J. Jarębska, I. Jaskólska, D. Jasiński, P. Kaleta, K. Okoniewska, J. Wysocki, P. Pokora, S. Tomczak, W. Siudek, pod red. P. Pokory, przy współpracy M. Hlebionka, tłum. E. Jiya, D. Młodzianowska-Pilczuk, Poznań 2015.

\title{
Szymon Bauman, Paulina Chrząszcz
}

\section{Wytwórcy i sprzedawcy pieczęci ogłaszający się w prasie poznańskiej w latach 1815-1939}

\begin{abstract}
Streszczenie
Niniejszy artykuł wychodzi naprzeciw potrzebom badawczym sfragistyki XIX i XX stulecia, prezentując wyniki badań nad ogłoszeniami prasowymi wytwórców i sprzedawców pieczęci, które zamieszczano w prasie poznańskiej w latach 1815-1939. Treścią tego przyczynku jest wykaz osób wytwarzających pieczęcie i oferujących sprzedaż wyrobów pieczętarskich, dzięki któremu udało się przedstawić dane do życia i działalności kilkudziesięciu rzemieślników oraz kupców tak z okresu rozbiorów, jak i dwudziestolecia międzywojennego. Zgromadzone krótkie dane osobowe mają pozwolić na rozszerzenie badań nad rzemiosłem i przyczynić się do uzupełnienia stanu badań o poznańskich rzemieślnikach pracujących w metalu.
\end{abstract}

Słowa kluczowe: Poznań, XIX i XX w., miasto, rzemiosło, handel, ogłoszenia prasowe, pieczętarz, grawer, sfragistyka, pieczęć, typariusz pieczętny

\section{Szymon Bauman, Paulina Chrząszcz}

\section{Makers and sellers of seals advertising their services in the Poznan press in the years 1815-1939}

\begin{abstract}
This article responds to the research needs regarding $19^{\text {th }}$-and $20^{\text {th }}$-century sigillography, presenting the results of research on press advertisements of seal makers and sellers published in the Poznan press in the years 1815-1939. This publication includes a list of people who produced seals and offered sales of the associated products, which made it possible to present information on the lives and activities of several dozen craftsmen and merchants from the period of the partitions and the interwar period in Poland. The personal data collected here allow for the development of research on craftsmanship and Poznań craftsmen working with metal.
\end{abstract}

Key words: Poznan, $19^{\text {th }}$ and $20^{\text {th }}$ century, city, craft, trade, press advertisements, seal maker, engraver, sigillography, seal, seal matrix 